\title{
A COMPREENSÃO DE FAMÍLIA SOB A ÓTICA DE PAIS E FILHOS ENVOLVIDOS NA VIOLÊNCIA DOMÉSTICA CONTRA CRIANÇAS E ADOLESCENTES
}

Dissertação apresentada ao Programa de PósGraduação do Departamento de Enfermagem Materno Infantil e Saúde Pública da Escola de Enfermagem de Ribeirão Preto da Universidade de São Paulo, para obtenção do título de Mestre em Enfermagem em Saúde Pública inserida na linha de investigação intitulada: Assistência à Criança e ao Adolescente.

RIBEIRÃO PRETO 


\section{A COMPREENSÃO DE FAMÍLIA SOB A ÓTICA DE PAIS E FILHOS ENVOLVIDOS NA VIOLÊNCIA DOMÉSTICA CONTRA CRIANÇAS E ADOLESCENTES}

Camilla Soccio Martins

Dissertação apresentada ao Programa de PósGraduação do Departamento de Enfermagem Materno Infantil e Saúde Pública da Escola de Enfermagem de Ribeirão Preto da Universidade de São Paulo, para obtenção do título de Mestre em Enfermagem em Saúde Pública inserida na linha de investigação intitulada: Assistência à Criança e ao Adolescente.

Orientadora: Prof ${ }^{\mathrm{a}} \mathrm{Dr}^{\mathrm{a}}$ Maria das Graças Bonfim de Carvalho 
Autorizo a reprodução total ou parcial deste trabalho, por qualquer meio convencional ou eletrônico, para fins de estudo e pesquisa, desde que citada a fonte.

FICHA CATALOGRÁFICA

Martins, Camilla Soccio

A compreensão de família sob a ótica de pais e filhos envolvidos na violência doméstica contra crianças e adolescentes. Ribeirão Preto, 2005.

136 p. $30 \mathrm{~cm}$

Dissertação (Mestrado - Programa de Pós Graduação em Enfermagem. Área de Concentração: Enfermagem em Saúde Pública) - Escola de Enfermagem de Ribeirão Preto Universidade de São Paulo

Orientador: Maria das Graças Bonfim de Carvalho

1. Família. 2. Violência Doméstica. 3. Criança e adolescente 
FOLHA DE APROVAÇÃO

Camilla Soccio Martins

A compreensão de família sob a ótica de pais e filhos envolvidos na violência doméstica contra crianças e adolescentes.

Dissertação apresentada à Escola de Enfermagem de Ribeirão Preto da Universidade de São Paulo para obtenção do título de Mestre em Enfermagem em Saúde Pública.

Aprovado em:

Banca Examinadora

Profa. Dra.

Julgamento: Assinatura:

Profa. Dra.

Julgamento: Assinatura:

Profa. Dra.

Julgamento: Assinatura: 
A minha mãe e irmão

"HOJE NÓS TREAS, DE MÃOS DADAS. SOMOS PAIS F FILHOS DOS NOSSOS SONHOS" 


\section{AGRADECIMENTOS}

Às todas as crianças e adolescentes vítimas da violência doméstica que, de alguma forma, transformam suas tristes experiências em valiosos aprendizados.

À Prof Dr Maria das Graças Bonfim de Carvalho pela confiança, profissionalismo, amizade e, principalmente, por acreditar que a realização desse trabalho seria possível.

À Mayra, Taísa, Mônica e Angélica, alegres flores que perfumam meu caminho.

Ao Marcelo que transforma minha árdua e longa caminhada em doces momentos.

À Eliana Roque e Silvia Dib que com preciosa dedicação contribuíram para o meu desenvolvimento profissional.

À Maria Eliza e Simone pela disponibilidade e incondicional paciência.

À todos os docentes e funcionários que estiveram presente na minha jornada, enquanto aluna de Pós-Graduação, da Escola de Enfermagem de Ribeirão Preto - USP.

À Secretaria do Departamento de Enfermagem Materno-Infantil e Saúde Pública, representada pela Olânia, Augusto, Adriana e Andréia, pela, competência e amizade sempre presentes.

À Coordenação de Aperfeiçoamento de Pessoal de Nível Superior (CAPES) e 'a Fundação de Amparo à Pesqisa do Estado de São Paulo (FAPESP) que possibilitaram a realização deste trabalho. 


\section{LISTA DE ABREVIATURAS E SIGLAS}

RESUMO

RESUMEN

ABSTRACT

1. INTRODUÇÃO ........................................................................................... 2

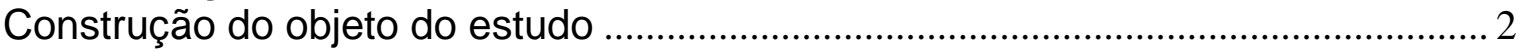

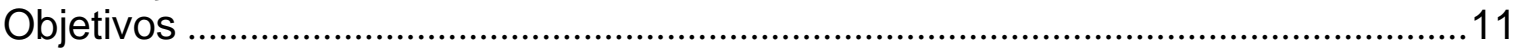

2. MARCO TEÓRICO ........................................................................................ 12

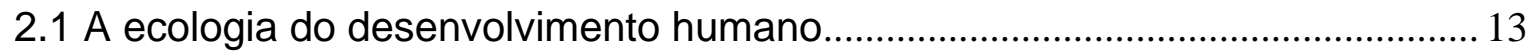

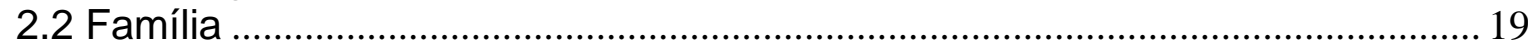

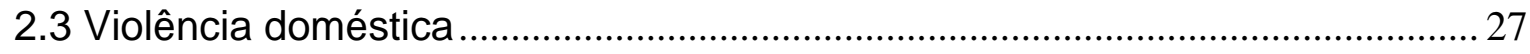

2.4 Política de atenção à criança e ao adolescente................................................. 36

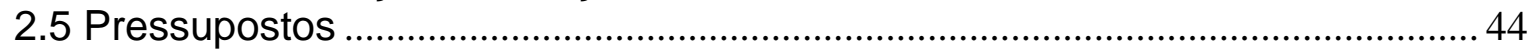

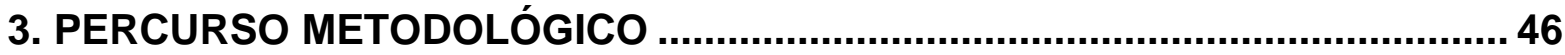

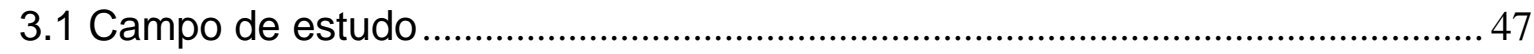

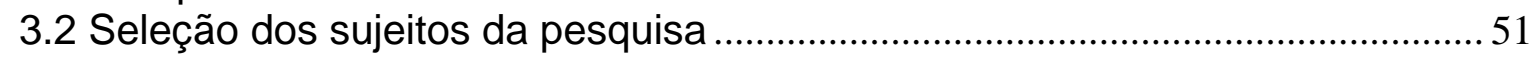

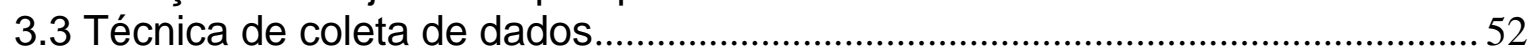

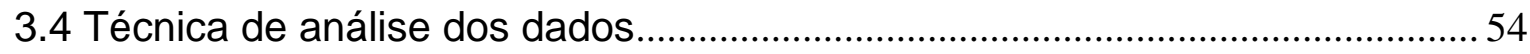

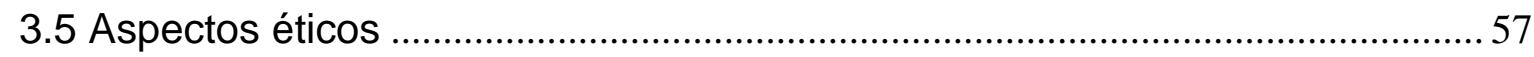

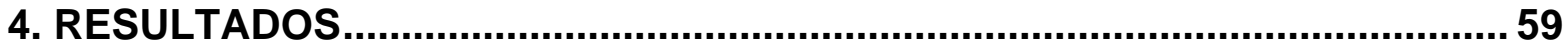

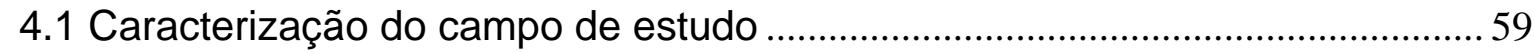

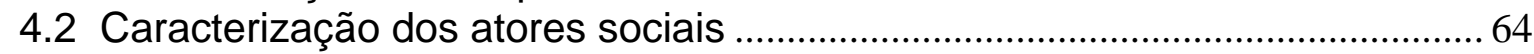

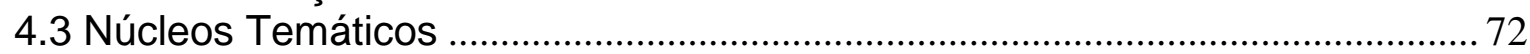

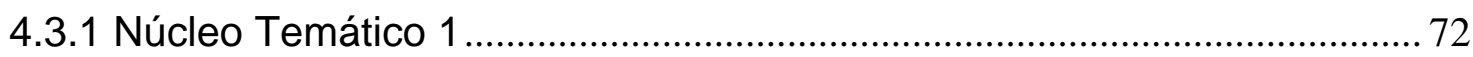

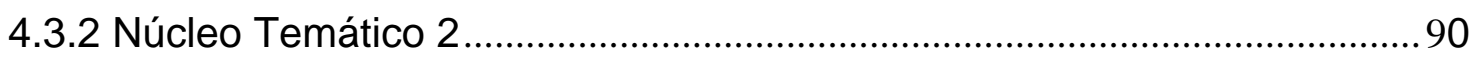

5. CONSIDERAÇÕES FINAIS ................................................................ 104

6. REFERÊNCIAS.................................................................................... 111

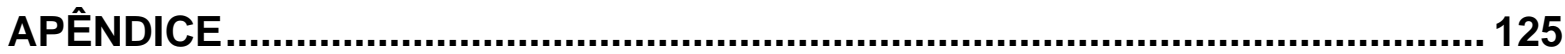

ANEXO 
ABRAPIA Associação Brasileira Multiprofissional de Proteção à Infância e Adolescência

CACAV Centro de Atendimento à Criança e Adolescente Vitimizado

CARIB Centro de Adoção de Ribeirão Preto

CECRIA Centro de Referência, Estudos e Ações sobre Crianças e

Adolescentes

ECA Estatuto da Criança e do Adolescente

FUNDET Fundação de Educação para o Trabalho

MS Ministério da Saúde

MJ Ministério da Justiça

OMS Organização Mundial da Saúde

ONG Organização Não-Governamental

ONU Organizações das Nações Unidas 
OPAS Organização Pan-Americana de Saúde

SBP $\quad$ Sociedade Brasileira de Pediatria

SEADE Sistema Estadual de Análise de Dados

SEBES Secretaria do Bem Estar-Social

UBDS Unidade Básica Distrital de Saúde

UBS Unidade Básica de Saúde

Unicef United Nations Internacional Children's Emergency Fun

(Fundo das Nações Unidas para a Infância) 


\section{RESUMO}

MARTINS, C. S. A compreensão de família sob a ótica de pais e filhos envolvidos na violência doméstica contra crianças e adolescentes. 2005. 136p. Dissertação (Mestrado) - Escola de Enfermagem de Ribeirão Preto, Universidade de São Paulo, Ribeirão Preto, 2005

Atualmente um amplo processo de mobilização social contra a violência, nas famílias, tornou-se urgente. O serviço de saúde é um espaço privilegiado para se atuar sobre o campo da violência doméstica e são encontradas inúmeras dificuldades em lidar com o fenômeno por parte dos profissionais da área. Nesse sentido, acreditamos que a falta de uma compreensão mais ampla sobre o contexto familiar é uma das dificuldades que está relacionada à falta de conhecimento sobre o assunto. A investigação, aqui apresentada, buscou conhecer e analisar a compreensão de família para pais e filhos envolvidos no episódio da Violência Doméstica contra crianças e adolescentes institucionalizados no Centro de Atendimento à Criança e ao Adolescente Vitimizado (CACAV). A metodologia adotada é de abordagem qualitativa e utilizamos como instrumento de coleta de dados a entrevista semi-estruturada aplicada aos pais e às crianças que foram vitimizadas, totalizando seis famílias. Quanto à análise desses dados, escolhemos a análise de conteúdo, modalidade temática, proposta por Bardin (1979). O referencial teórico que subsidiou nossa análise de dados foi o modelo centrado na visão do contexto ecológico do desenvolvimento humano proposto por Urie Bronfenbrenner. Identificamos, a partir das falas dos entrevistados, duas temáticas: "contexto familiar" e "violência". Em relação à primeira temática, apreendeu-se que a visão dos pais sobre família é diferente da visão das crianças e adolescentes vitimizados, uma vez que a ótica dos pais favorece a compreensão da família como nuclear dentro de uma perspectiva que ainda permanece cultural e socialmente estabelecida pela sociedade. Já as crianças apontam que o vínculo de amor e afeição são mais significativos que laços consangüíneos, tal fato pode estar relacionado à vitimização, considerando que a violência doméstica contribui para o enfraquecimento do sentimento de família. Em relação à segunda temática, evidenciamos que o fato da criança e do adolescente testemunharem ou vivenciarem a violência doméstica tenderá a reproduzir, por sua vez, relacionamentos violentos em seu cotidiano, fazendo com que seja perpetuada a cadeia desse tipo de violência. Acreditamos que tais perspectivas apresentadas neste estudo, dentro de um contexto de significados, refletem a realidade pela qual passa a família, facilitando, assim, a prevenção desses eventos. Dessa forma, é importante considerar que a partir do conhecimento da dinâmica familiar e da forma como a violência é experienciada pelas suas vítimas e agressores é que podemos pensar em uma estratégia de intervenção capaz de romper o ciclo perverso das relações familiares violentas.

Palavras-Chave: Família, violência doméstica, criança e adolescente. 


\section{RESUMEN}

MARTINS, C. S. La comprensión de la familia bajo la óptica de padres e hijos involucrados en la violencia doméstica contra niños y adolescentes. 136p. 2005. H. Disertación (Maestría) - Escuela de Enfermería de Ribeirão Preto, Universidad de São Paulo, Ribeirão Preto, 2005

Actualmente se hace urgente un amplio proceso de movilización social contra la violencia. El servicio de salud es un espacio privilegiado para actuarse sobre el campo de la violencia doméstica y los profesionales de esta área encuentran innumerables dificultades al enfrentar el fenómeno. En este sentido, creemos que la falta de una comprensión más amplia sobre la aproximación familiar sea una de las dificultades, que está relacionada a la falta de conocimiento sobre el asunto. La finalidad de esta investigación fue conocer y analizar la comprensión de familia por padres e hijos involucrados en episodios de violencia doméstica contra niños y adolescentes institucionalizados en el Centro de Atención al Niño y al Adolescente Victimizado (CACAV). La metodología adoptada es de aproximación cualitativa y utilizamos como instrumento de recopilación de datos la entrevista semiestructurada, aplicada a los padres y los niños victimizados, totalizando 6 familias. Respecto al análisis de eses datos, elegimos el análisis de contenido en su modalidad temática, propuesta por Bardin (1979). El referencial teórico que apoyó nuestro análisis de datos fue el modelo centrado en la visión del contexto ecológico del desarrollo humano propuesto por Urie Bronfenbrenner. A partir del discurso de los entrevistados, identificamos dos temáticas: "contexto familiar" y "violencia". Respecto a la primera temática, se observo que la visión de los padres sobre familia es diferente de la visión de los niños y adolescentes victimizados, ya que la óptica de los padres favorece la comprensión de la familia como siendo nuclear, dentro de una perspectiva que todavía permanece culturalmente y socialmente establecida por la sociedad. Los niños indican que los vínculos de amor y afección son más significativos que lazos consanguíneos. Tal hecho puede estar relacionado a la victimización, considerando que la violencia doméstica contribuye al enflaquecimiento del sentimiento de familia. Respecto a la segunda temática, evidenciamos que, debido al hecho de que el niño y el adolescente presencian o viven la violencia doméstica, tenderán a reproducir, por su vez, relaciones violentas, haciendo con que sea perpetuada la cadena de transmisión dese tipo de violencia. Creemos que las perspectivas presentadas en este estudio, dentro de un contexto de significados, reflexionen la realidad por la que pasa la familia, facilitando, así, la prevención de esos eventos. De esta forma, es importante considerar que es a partir del conocimiento de la dinámica familiar y de la forma como la violencia es vivida por sus víctimas y agresores que podemos pensar en una estrategia de intervención capaz de romper el ciclo perverso de las relaciones familiares violentas.

Palabras-Clave: Familia, violencia doméstica, niño y adolescente. 


\section{ABSTRACT}

MARTINS, C. S. Understanding the family from the perspective of parents and children involved in domestic violence against children and adolescents. 2005. 136p. Masters Dissertation - Ribeirão Preto College of Nursing, University of São Paulo, Ribeirão Preto, 2005.

Nowadays, there is an urgent need for a broad social mobilization process against family violence. The health service is a privileged space to act in the field of domestic violence. Health professionals face countless difficulties to deal with this phenomenon. In this sense, we believe that one of these difficulties refers to the lack of a fuller understanding about the family approach, which is related to a lack of knowledge about the subject. This research aimed to get to know and analyze how parents and children involved in episodes of domestic violence against children and adolescents, institutionalized at the Care Center for Child and Adolescent Victims (CACAV). A qualitative methodology was adopted and data were collected by means of semi-structured interviews with parents and child victims, totaling 6 families. Content analysis was chosen to analyze these data, using the thematic mode proposed by Bardin (1979). The theoretical reference framework that guided our data analysis was the model centered on Urie Bronfenbrenner's view of the ecological context of human development. Based on the interviewees' discourse, we identified two themes: "family context" and "violence". With respect to the first theme, we observed that the parents' view on family differs from that of the child and adolescent victims, since the parents' point of view favors an understanding of family as the core, within a perspective that is still culturally and socially established by society. Children, on the other hand, indicate that bonds of love and affection are more important than blood relations. This fact may be related to victimization, since domestic violence contributes to the weakening of family feelings. What the second theme is concerned, we demonstrate that, due to the fact that children and adolescents witness or experience domestic violence, they will tend to reproduce violent relations, thus perpetuating the transmission chain of this kind of violence. We believe that, within a context of meanings, the perspectives presented in this study reflect the reality the family goes through, thus making it easier to prevent these events. Hence, it should be taken into account that it is on the basis of knowledge about the family dynamics and how violence is experienced by its victims and aggressors that we can think of an intervention strategy that is capable of breaking the perverse cycle of violent family relations.

Keywords: Family, domestic violence, child and adolescent. 


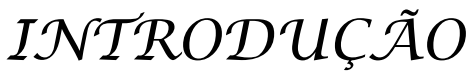




\section{INTRODUÇÃO}

\section{Construção do objeto do estudo}

4 magnitude do problema da violência na atualidade vem ganhando destaque devido à repercussão dos seus prejuízos na sociedade. Minayo e Souza (1999) acrescentam que a violência é fundamentalmente considerada uma questão de âmbito social e histórico, manifestando-se nas relações políticas, culturais e pessoais dos indivíduos. Hoje podemos dizer que a violência se estrutura em padrões culturalmente introjetados e manifesta-se contínua e veladamente.

Segundo a mesma autora, a violência no Brasil ocupava o quarto lugar no perfil de mortalidade geral na década de 1960. Já na década de 1980 e 1990 ela passa para o segundo lugar no obituário por causas externas.

A ORGANIZAÇÃO MUNDIAL DA SAÚDE - OMS (2002) estima que no ano de 2000 houve 57 mil óbitos entre crianças e adolescentes com idade inferior a 15 anos por homicídio.

Um fator relevante que podemos observar em relação à violência é sua banalização através da mídia e em outros veículos de comunicações, em que suas expressões sociais percorrem várias direções e assumem formas que tornam inviável, politicamente, o enfrentamento de suas manifestações. O custo 
Introdução

Camilla Soccio Martins

daviolência estimado pela OMS (2002) é da ordem de bilhões de dólares gastos em todo o mundo com assistência à saúde.

As diversas formas de violência não são encontradas apenas no âmbito das relações interpessoais, observamos, portanto, que estão presentes no dia-adia das grandes instituições que, de alguma forma, exercem poder na sociedade, como a escola, a família, os meios de comunicação, a igreja, etc.

Minayo e Assis (1993) apud Medeiros (2000) situam a violência a partir de quatro níveis:

- Violência estrutural, referente àquela que se sustenta nas desigualdades sociais, estando relacionada a situação de miséria e pobreza, características das sociedades marcadas pela dominação de classes e por enormes desigualdades na distribuição de renda (MINAYO, 1994).

Minayo e Souza (2002), referem ainda que a violência estrutural "incide sobre a condição de vida das crianças e adolescentes, a partir de decisões histórico-econômica e sociais, tornando vulnerável o seu crescimento e desenvolvimento" (p.99) e que por ter caráter de perenidade e se apresentar sem a intervenção dos indivíduos, esta forma de violência aparece "naturalizada" como se não houvesse nela a ação de sujeitos. 
Introdução

Camilla Soccio Martins

- Violência cultural, que transcende ás relações étnicas, grupos etários ou familiares;

- Violência da delinqüência, que se manifesta no que a sociedade considera crime;

- Violência de resistência, marcada pela reação dos sujeitos e grupos socialmente dominados por outros.

Assim, a violência doméstica, seja contra crianças, adolescentes, mulheres, homens ou idosos, não pode deixar de ser reconhecida e entendida como um fenômeno, articulado a violência estrutural e social a que os sujeitos, suas famílias e sociedade em que vivem estão expostos.

Atualmente um amplo processo de mobilização social contra a violência nas famílias tornou-se urgente, no entanto encontramos uma "condescendência social que obstaculiza sua denúncia e cria as bases da sua impunidade" (BRASIL, 2001b).

Na Constituição Federal é fixado o artigo 227 que diz:

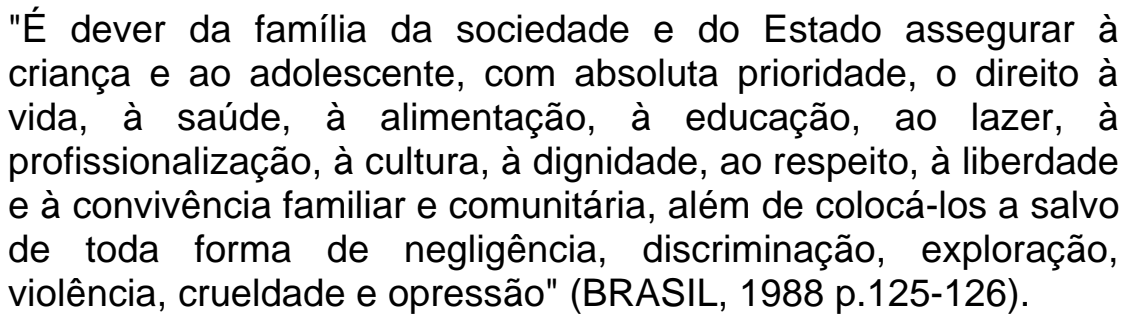

A violência praticada contra crianças e adolescentes, freqüentemente, é caracterizada por um abuso do poder disciplinador e coercivo dos pais ou 
Introdução

Camilla Soccio Martins

responsável, em que a vítima é completamente objetificada e seus direitos fundamentais, como a vida, a liberdade e a segurança, são desrespeitados. Essa subordinação de crianças e adolescentes a diversas formas de maus-tratos no ambiente familiar pode ter duração indefinida devido à sacralidade dessa instituição e à autoridade que os pais exercem sobre os filhos, impondo-lhes um pacto de silêncio e, por vezes, de cumplicidade (GUERRA; SANTORO; AZEVEDO, 1992).

O fato de a violência ocorrer dentro da família denuncia a falta de estruturação familiar que poderia ser o referencial para o desenvolvimento psicológico e social de seus membros. Podemos dizer que a violência doméstica rompe o vínculo de confiança básica para o desenvolvimento da vida em família, entrando na seara das relações familiares e seus significados.

Como expôs Ribeiro (2002), em nosso país, prevalece uma vasta dificuldade em conhecer a dimensão exata dos casos de violência doméstica, pois tal situação permanece sendo um assunto privado tratado no território sagrado da família, a vergonha e muitas vezes o medo são fatores que dificultam estatísticas confiáveis.

O interesse pela questão da violência adveio da experiência enquanto graduanda de enfermagem e bolsista de iniciação científica desenvolvendo estudos com o tema "violência doméstica" inserido em um Projeto Temático intitulado: "A CRIANÇA E O ADOLESCENTE NA ESCOLA, FAMÍLIA E COMUNIDADE, ALVOS DE ATOS VIOLENTOS OU VÍTIMAS POTENCIAIS DA VIOLÊNCIA" financiado pela Fundação de Amparo à Pesquisa do Estado de São 
Paulo - FAPESP, processo no 99/08492-0, cujo objetivo foi analisar as diferentes iniciativas de proteção à infância e adolescência bem como situações em que crianças e adolescentes são alvos violentos ou vítimas potenciais da violência para que se possam estabelecer princípios de ação no campo da prevenção e assistência em saúde (FERRIANI, 2000).

A inquietação acerca da violência também emergiu com o enfrentamento da enfermagem nos últimos anos com essa questão. A violência contra crianças e adolescentes quer seja na área de saúde, nas unidades básicas e hospitais, quer seja nas atividades desenvolvidas em escolas, creches e pré-escolas, necessita da obtenção de dados que possam dar visibilidade a um tema que carece da criação de políticas públicas para subsidiar ações de prevenção, proteção e assistência à família vitimizada.

No transcorrer do levantamento bibliográfico sobre o tema ainda na graduação, descobrimos que o fenômeno da violência doméstica é polimórfico e multifacetado e dentre as suas múltiplas formas, despertou-nos o interesse e a curiosidade de investigar um pouco sobre a Violência Sexual, como parte de um projeto de iniciação científica, pela carência de estudos a respeito e por se mostrar como um grave problema para o setor da saúde.

No Brasil, dados globais são quase inexistentes a respeito do fenômeno, estima-se que menos de 10\% dos casos chegam às delegacias (BRASIL, 1999).

Então, caracterizamos através de registros em uma casa-abrigo esse tipo de violência, suas vítimas e agressores através do trabalho intitulado: 
Introdução

Camilla Soccio Martins

"Caracterização dos agressores e vítimas de violência sexual intrafamiliar: um estudo de caso" (MARTINS; FERRIANI, 2003a).

Seus resultados mostraram que cerca de $90 \%$ dos agressores nos casos de violência doméstica são os pais biológicos ou padrastos, o que reflete a relação direta entre violência e gênero:

\begin{abstract}
"O poder e o domínio masculino favorecem estilo de relação de imposição sobre os mais fracos (...) Os abusos sexuais e suas consequências (como a prostituição) seriam uma reprodução do funcionamento de sistemas humanos macrossociais onde os homens e os adultos, aproveitando-se abusivamente do seu poder, utilizam as crianças e as mulheres para satisfazer suas necessidades e resolver seus conflitos" (BRAVO, 1994, p. 144).
\end{abstract}

Além de existir uma necessidade de uma maior resolutividade nas questões sociais e jurídicas que envolvem esse tipo de violência, ela geralmente costuma ser expressada associadamente com outras modalidades de violência. Isso incentivou-nos a continuar, ainda na iniciação científica, conhecer outra modalidade de violência, a Violência Física, pois a violência doméstica, apesar de se manifestar de várias formas, é mais evidenciada através da Violência Física. Foi a partir dessa questão que surgiu outro trabalho intitulado: "Caracterização da violência física contra crianças e adolescentes" (VIEIRA; MARTINS; FERRIANI; NASCIMENTO, 2004).

Os resultados dessa pesquisa revelaram dados a respeito desse tipo de violência. No ano de 1998, foram feitas 303 denúncias de casos de violência física 
Introdução

Camilla Soccio Martins

na região sudoeste da cidade de Ribeirão Preto-SP, exceto aqueles considerados subnotificados.

Conhecendo mais um pouco dessas violências, finalizando a iniciação científica na graduação, nos interessou saber como essas crianças e adolescentes que sofreram algum tipo de violência doméstica reintegram-se à família e sociedade. A partir do exposto desenvolvemos um terceiro trabalho intitulado: "Reintegração da criança e do adolescente vitimizados na percepção dos pais" (MARTINS; FERRIANI, 2003b).

Mais uma vez os resultados obtidos trouxeram outros aspectos relevantes sobre a violência doméstica, por ser ela, uma forma própria de relação pessoal, política, social e cultural. Contudo a inquietação sobre a problemática não cessou e na tentativa de elucidar diversos aspectos desse trama social é que entramos no campo das relações familiares e seus significados através de um projeto de mestrado, buscando na literatura embasamento teórico-científico e estruturando este atual estudo.

Sabemos que o serviço de saúde é um espaço privilegiado para se atuar no campo da violência doméstica e que são encontradas inúmeras dificuldades em lidar com o fenômeno por parte dos profissionais da área. Entre algumas dessas dificuldades está o desconhecimento e despreparo desses profissionais para identificação, atendimento e encaminhamento das vítimas, a dificuldade em proceder a notificação dos casos confirmados e a inabilidade em lidar com os agressores. 
Introdução

Camilla Soccio Martins

Acreditamos que a falta de uma compreensão mais ampla sobre a dinâmica familiar é a maior dificuldade e está relacionada à falta de conhecimento sobre o assunto, já que a violência doméstica se apresenta em formas diversas que exige do profissional conhecimentos prévios sobre o assunto. Além disso, a compreensão do comportamento ou necessidades de um indivíduo pode claramente ser alcançada, quando o contexto familiar é trazido para o processo de análise da situação. A família é um importante recurso para prestar cuidado de saúde, pois qualquer problema que afete um ou mais membros familiares, poderá afetar outros membros, bem como toda a família.

Poucos estudos sobre crianças e adolescentes vitimizados dentro da família foram detectados. As investigações nesse campo têm privilegiado a ótica dos adultos envolvidos, sejam os pais/responsáveis ou os agentes que passam a cuidar desses jovens. Algumas pesquisas, entretanto, destacam a importância de se investigar o ponto de vista da criança/adolescente em relação a aspectos dessas vivências.

Por exemplo, De Antoni; Simões; Martins; Costa; Ferronato; Maurente e Koller (2000) investigaram a visão de família em um grupo de crianças e adolescentes vitimizados, concluindo que a configuração familiar e os papéis desempenhados pelos membros da família são percebidos pelos sujeitos de uma forma bastante rígida. Numa investigação paralela, esses mesmos autores buscaram identificar os indicadores de risco e proteção na família na ótica de adolescentes abrigados sob medida de proteção. 
A enfermagem, no campo da violência doméstica, abrange uma série de ações, que visam a assistência integral da criança e do adolescente, tais como: identificação da violência, encaminhamento das vítimas e agressores, notificação dos casos confirmados e prevenção desses fenômenos.

Portanto, é com a perspectiva de produzir um conhecimento, que é parte dessa realidade, que visualizamos a questão da compreensão de família para pais, filhos e/ou responsáveis, vítimas da violência doméstica, objeto do presente estudo, partindo de algumas questões:

- Qual a compreensão de família para as pessoas do núcleo familiar envolvidas na violência doméstica?

- Como a violência doméstica correlaciona-se com o significado de família?

- Como é a dinâmica da reprodução da violência no contexto da família?

Frente a esses questionamentos, buscamos aprofundar conhecimentos, bem como compreender o que é família através do levantamento na literatura sobre o tema, ancorando os conceitos mais utilizados sobre família, bem como a historicidade desse tema, buscamos tecer considerações sobre o fenômeno da violência doméstica com vistas a subsidiar e responder aos objetivos e pressupostos da pesquisa. 


\section{Objetivos}

Objetivo geral

- Conhecer e analisar a compreensão de família para pais e filhos envolvidos no episódio da Violência Doméstica contra crianças e adolescentes institucionalizados no Centro de Atendimento à Criança e ao Adolescente Vitimizado (CACAV).

Objetivos específicos

- Identificar as relações de significados de família com a situação de violência doméstica contra crianças e adolescentes.

- Conhecer e analisar a reprodução do ciclo da violência doméstica no contexto da família. 
$\mathcal{M} \mathcal{A R C O} \mathcal{T} \mathcal{E} O ́ R I C O$ 


\section{MARCO TEÓRICO}

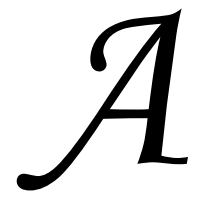

problemática da violência na família passa a ser tarefa complexa na sociedade atual, com suas características e dimensões peculiares em relação a vários aspectos sociais, morais, geopolíticos, históricos, econômicos e psicológicos. Daí a necessidade de se elencar como se fez a trajetória histórica das famílias no intuito de compreendermos melhor nosso objeto de estudo.

Escolhemos como referencial teórico para analisar a família, um recorte do modelo do desenvolvimento humano proposto por Urie Bronfenbrenner (1996), pois a violência doméstica não pode ser explicada por modelos teóricos deterministas ou unidimensionais os quais atribuem à causalidade linear justificativas para o fenômeno.

Esse referencial conceitua a família como uma unidade funcional que ocorrem dinâmicas de relações, entre os seus membros, simétricas ou assimétricas marcadas ou não por desigualdades e subordinações.

Buscamos também, na produção brasileira e internacional, as trajetórias históricas da família e da violência doméstica, não deixando de trazer conceitos de alguns autores acerca destas questões, além de pesquisas realizadas nos últimos quatro anos a respeito do fenômeno. Achamos interessante trazer questões da política de atenção à criança e ao adolescente entendendo que é papel do Estado e da sociedade o enfrentamento desse tipo de violência, dando visibilidade ao fenômeno. 


\subsection{A ecologia do desenvolvimento humano}

Para entender melhor como a família configura-se diante da violência doméstica de maneira ampla e sistêmica, embasamos nossa análise, como já mencionado, em um recorte do modelo ecológico do desenvolvimento humano proposto por Urie Bronfenbrenner (1996).

O estudo das relações sociais violentas dentro da família requer uma estrutura teórica capaz de explicar as variáveis causais no seu contexto mais amplo. Nesse sentido, a Teoria de Bronfenbrenner dos Sistemas Ecológicos nos traz subsídios para compreender a família em seu contexto de desenvolvimento e as complexas relações entre seus membros.

O termo "Ecológico" é empregado para designar um ambiente natural, objetos e atividades da vida cotidiana no contexto da pesquisa. Já o desenvolvimento humano é entendido como uma transformação duradoura na maneira pela qual uma pessoa percebe e lida com o seu ambiente, sendo o ser humano considerado uma entidade em crescimento e dinâmica, que progressivamente penetra no meio em que reside e o reestrutura.

Segundo este referencial, o microssistema é um conjunto de papéis desempenhados e relações interpessoais experienciados pela pessoa em desenvolvimento num dado ambiente com características físicas e materiais específicas. O termo "experienciado" é designado para indicar o modo como a pessoa percebe as propriedades do ambiente, que vai além da sua propriedade objetiva. 
Marco Teóríco

Camilla Soccio Martins

O microssistema é o primeiro ambiente que o ser humano em desenvolvimento se insere de acordo com os padrões societais. Esse ambiente possui atividades e relacionamentos que são associados a determinados comportamentos e expectativas, como, por exemplo, a relação da mãe com a criança. Fatos ocorridos em um microssistema estão relacionados e se entrelaçam com o que acontece nos outros microssistemas.

Como um sistema de encaixes contidos uns nos outros, o microssistema está inserido nos sistemas mais amplos que influencia e é influenciado. Os demais sistemas são denominados: mesossistema, exossistema e macrossistema.

O mesossistema constitui-se na interação de dois ou mais ambientes em que a pessoa participa ativamente, como, por exemplo o ambiente de trabalho, as relações com a vizinhança, com a escola e com outros grupos sociais. Essas relações são interdependentes entre si e podem dificultar ou promover o desenvolvimento do sistema familiar e de seus membros. As relações da família com a escola podem afetar de forma positiva ou negativa o desempenho escolar de uma criança, por exemplo. Então um mesossistema é um sistema de microssistemas.

Já o exossistema compreende os ambientes nos quais apenas um ou mais membros da família mantêm relações diretas. No entanto, essa relações se refletem indiretamente nos outros membros que não participam deste ambiente (BRONFENBRENNER, 1996). Exemplo de exossistema de uma criança pequena: 
Marco Teóríco

Camilla Soccio Martins

o local de trabalho dos pais, uma sala de aula de um irmão mais velho, a rede de amigos dos pais, as atividades da diretoria da escola local e assim por diante.

O macrossistema é o sistema mais amplo e abrange todos os outros. Ele é formado por um padrão global de ideologias, crenças, valores e organização social comum à uma determinada cultura. Os planejamentos dos sistemas diferem para os vários grupos socioeconômicos, étnicos, religiosos e outros grupos subculturais, refletindo sistemas de crenças e estilos de vida contrastantes, abrangendo possíveis planejamentos para o futuro conforme refletidos na visão dos líderes políticos, planejadores sociais, filósofos e cientistas sociais de uma sociedade, engajados na análise crítica e na alteração experimental dos sistemas sociais prevalentes. É ao mesmo tempo um produto e um produtor da mudança desenvolvimental.

As políticas sociais de combate à violência e de promoção de educação e saúde são exemplos de macrossistema que influenciam diretamente no desenvolvimento do sistema familiar. A violência doméstica se insere no microssistema, pois se manifesta nas relações pais-filhos, contudo, pode ter essencialmente suas causas e conseqüências no sistema subseqüente ou até mesmo no macrossistema.

Bronfenbrenner (1996) destaca características que existem dentro das relações familiares: o afeto, a reciprocidade e o poder. O afeto é fundamental para o desenvolvimento da criança e do adolescente e é manifestado através de relações positivas e atenciosas. A reciprocidade é caracterizada pela influência que um membro da família exerce sobre o outro e vice-versa. O equilíbrio do 
Marco Teóríco

Camilla Soccio Martins

poder deve ser sempre em direção do desenvolvimento da criança e do adolescente para oferecer-Ihes a oportunidade de aprender a lidar com relações de poder. De acordo com Bronfenbrenner (1996, p.47): “O equilíbrio do poder é significativo quando esse equilíbrio gradualmente se altera em favor da pessoa em desenvolvimento; em outras palavras, quando esta última recebe uma crescente oportunidade de exercer controle sobre a situação".

No entanto, se há um desequilíbrio no poder, é comum originarem-se relações interpessoais assimétricas e hierárquicas, marcando a desigualdade e subordinação e levando à prática da violência doméstica. As forças ambientais, as características do agressor e as características das crianças ou do adolescentevítima atuam de maneira dinâmica e recíproca neste processo.

Ainda podemos dizer que é impossível compreender o comportamento unicamente a partir de propriedades objetivas de um meio ambiente, sem referência ao seu significado para as pessoas; e, especialmente, a importância do irreal e do imaginado, ou seja, o ambiente experienciado é um aspecto fundamental na interpretação do comportamento e desenvolvimento.

O modelo de Bronfenbrenner representa uma tentativa de superação de modelos unidimensionais, pois trabalha com uma natureza integradora decorrente da interação de fatores macro (sistema sócio-econômico-político) e micro (história de vida dos pais, funcionamento e estrutura familiar). Conforme Azevedo (2002), os modelos unidimensionais que explicam a violência estão todos ancorados no pressuposto determinista de causalidade linear, cujo componente desencadeador 
Marco Teóríco

Camilla Soccio Martins

da violência ou do abuso infanto-juvenil seria um problema psicológico ou individual dos pais agressores.

A família é ao mesmo tempo a fonte mais rica e menos utilizada de pesquisas sobre o impacto desenvolvimental dos sistemas ecológicos. Recentemente, as pesquisas têm tentado destacar as crianças como sujeitos em desenvolvimento e para tanto procurar a origem e a evolução dos problemas sociais vivenciados por elas e buscando alternativas de solução que sejam mais adequadas à realidade em que essas crianças vivem e ainda mais, estudar a criança implica estudar a socialização por meio da família (BIASOLI, 2001).

De acordo com o exposto acima, julgamos de fundamental importância, na nossa pesquisa, a compreensão, pelo ponto de vista da criança e adolescente e não só apenas dos pais, de como o ambiente familiar é experienciado nos diversos níveis de desenvolvimento ecológico.

Consideramos a importância de complementar nossa análise baseada no contexto ecológico com outros conceitos que são significativos para compreender e caracterizar o contexto familiar bem como a dinâmica da violência doméstica. Incluímos os conceitos de resiliência, vulnerabilidade, fatores de risco e proteção.

A resiliência é a capacidade que o indivíduo traz consigo de responder de forma mais consistente aos desafios e dificuldades desenvolvendo um autoconceito realista, autoconfiança e autoproteção.

No contexto da violência doméstica, a resiliência pode estar presente associada à fatores de proteção que a promovem. 
Marco Teóríco

Camilla Soccio Martins

Fatores de risco associa o conceito de vulnerabilidade à probabilidade de dano (SAITO, 2001). A presença de um ou mais fatores de risco pode favorecer o surgimento de comportamentos violentos dentro da família.

Ayres (1996) define a vulnerabilidade como aquela que se apresenta através de comportamentos associados às diferentes susceptibilidades, entretanto deve-se considerar aspectos sociais, culturais, familiares, educativas entre outras. No entanto, a vulnerabilidade se manifesta somente quando o risco está presente.

Por sua vez, os fatores de proteção se dizem respeito às influências que modificam, melhoram ou alteram respostas pessoais a determinados riscos de dasadaptação.

Os fatores de risco e proteção não são estáticos e lineares, vão mudando e se transformando de acordo com as situações experienciadas por cada um.

Portanto, vários aspectos contribuem positiva ou negativamente nesse contexto, e a violência doméstica pode se caracterizar pela fragilidade das relações interpessoais dentro da família e desestruturação de seus membros gerando um ciclo de acontecimentos que permeiam condutas de risco em crianças e adolescentes tais como: agressividade, evasão escolar, prostituição, uso e abuso de álcool e drogas.

Esse conjunto de conceitos nos dá visibilidade para compreendermos o significado das relações familiares para indivíduos que têm seu desenvolvimento prejudicado através da violência entre seus membros. 
Marco Teóríco

Camilla Soccio Martins

\subsection{Família}

Sabemos que a família passou por diversas transformações ao longo do tempo, nas distintas épocas históricas, nos diferentes contextos socio econômicos e religiosos.

A família, na concepção que temos hoje, é uma construção historicamente recente e da sociedade européia, da qual nos originamos através do processo de colonização do Brasil. A expressão "família" é derivado de famulus que significa escravo doméstico. De acordo com Engels (1997), essa expressão foi criada pelos romanos para definir um conjunto de pessoas que eram introduzidas nas tribos latinas para serviços de agricultura e escravidão. Esse conjunto de pessoas era liderado por um chefe que mantinha sob seu poder a mulher, alguns escravos e filhos.

De acordo com Ariès (1978), no final do século XVI temos uma idéia sugestiva da família medieval. Nessa época as crianças, independente da condição social, tinham pouca importância, constituindo, muitas vezes, um incômodo e para serem educadas eram entregues a outras famílias a partir dos sete anos de idade onde ingressavam na escola ou no mundo dos adultos, fazendo tarefas domésticas e serviços pesados. Só retornariam para suas famílias de origem entre os quatorze e dezoito anos de idade.

Ainda Ariès (1978) traz através da análise de quadros do período da renascença, crianças vestidas como adultas, ou seja, entre os séculos XIII e XVII a criança era vista como um adulto em miniatura, como se funcionasse afetiva e intelectualmente dentro da mesma lógica de um adulto. As etapas de crescimento 
Marco Teóríco

Camilla Soccio Martins

e desenvolvimento infantil eram totalmente ignoradas e o infanticídio nas camadas mais populares era realizado sob a forma de acidente, uma vez que a renda não era suficiente para sustentar uma criança.

A socialização da criança não era assegurada nem controlada pela família. A criança se afastava logo de seus pais, e podemos dizer que, durante séculos, a educação foi garantida pela aprendizagem na convivência da criança ou do jovem com o adulto, assim, a passagem da criança pela família e pela sociedade era muito breve e insignificante. A criança não chegava a sair de uma espécie de anonimato. Muitas crianças morriam de doenças, pois na época a medicina era ainda pouco desenvolvida.

O objetivo da composição da família era a conservação de bens, a prática comum de um ofício, a ajuda mútua quotidiana e o alvo principal da união não era o afeto. As trocas afetivas e as comunicações sociais realizavam-se predominantemente fora do núcleo familiar, no grupo social mais amplo (DIAS, 1992).

No final do século $X I X$ e início do século $X X$, a criança passa por um processo de disciplinamento em decorrência do movimento médico-higienista estruturado em conseqüência da Primeira Guerra Mundial. Esse movimento trouxe a noção da sobrevivência através de um corpo sadio, sendo a criança submetida a cuidados e à regularidade de hábitos para que ela se torne autodisciplinada, no entanto, a criança ainda é vista com pouca importância e intolerância. 
Marco Teóríco

Camilla Soccio Martins

O "sentimento de família", segundo Fonseca (1997), tal como é conhecido a partir do século $X X$, resultou de uma transformação da família que passou da realidade moral e social à realidade afetiva, ocorrida em fins do século XVII e início do século XIX; produto de uma revolução qualitativa no terreno das representações mentais, ocorrido junto com importantes transformações, no âmbito de revoluções sociais, econômicas e políticas.

A Revolução Industrial, durante a primeira metade do século XIX, consolida o novo modelo de família moderna, caracterizada pela sociedade burguesa, estando ligado à necessidade do modo de produção capitalista, visando buscar preservar as forças de produção (BILAC, 1978).

A partir de então o sentimento de infância era o da "disciplina", que inspira toda a educação até o século XX. Deste modo, a família passou a ocupar um lugar novo na sociedade através do processo de educação dos filhos. A família passou a se organizar em torno da criança, esta saiu do anonimato e a família e a profissão passaram a ser os focos principais de interesse dos adultos (COSTA, 1983).

Foi nesse período que a família se transformou no tipo nuclear, ou seja, constituído de pai, mãe e filhos, também chamada de "família patriarcal" caracterizada pela autoridade masculina e distribuição rígida e hierárquica de papéis onde o patriarca é o chefe da família responsável pelo sustento material da família, enquanto à mulher cabem as tarefas domésticas e educação dos filhos. Sarti (1997) salienta que o trabalho, a família, o amor, a sexualidade e o 
Marco Teóríco

Camilla Soccio Martins

casamento que antes eram papéis estabelecidos passam a representar a individualidade e isso adquire uma grande importância social.

Passando para o mundo contemporâneo, vamos resgatar alguns fatos importantes e responsáveis pelas alterações na estrutura familiar. A necessidade de desenvolvimento econômico, a urbanização, a universalização, a miscigenação e o avanço extraordinário dos meios de comunicação favoreceram, pela própria necessidade de adaptação do homem ao novo meio que foi obrigado a conviver, a alteração de alguns padrões e conceitos familiares (COSTA, 1999).

Temos que no início da década de 1940 práticas e valores se alteram radicalmente, a criança começa a ser percebida como objeto de afeto e fonte de aprendizagem.

Já na década de 1970 surge o movimento chamado de feminismo, defendendo os direitos sociais das mulheres iguais aos dos homens. A liberdade da mulher, a segurança dos métodos anticoncepcionais, o aperfeiçoamento da fecundação in vitro, a liberdade sexual e o aumento do número de divórcios repercutiram na nova estrutura familiar, mudando a concepção do casamento como um laço indissolúvel. Mesmo com o feminismo revigorando, ainda temos que na década de 1980 predominava a estrutura hierárquica da família baseada na autoridade paterna sobre os filhos e a mulher.

O avanço mais atual no contexto familiar que reconhecemos hoje é o avanço jurídico advindo com a implementação do Novo Código Civil Lei n. 10406, de 10 de janeiro de 2002. A sua inovação trouxe significativas mudanças à medida que elimina a discriminação de gênero. Entre essas mudanças citamos a 
Marco Teóríco

Camilla Soccio Martins

alteração do termo Pátrio Poder para Poder familiar, estabelecendo que a guarda dos filhos passa a ser do cônjuge com melhores condições de exercê-la, institui que o pai ou mãe que contrai nova união estável, não perde quanto aos filhos de relacionamento anterior o poder familiar, substitui o termo "homem", quando usado genericamente para referir ao ser humano pela palavra "pessoa" e ainda permite ao marido adotar o sobrenome da mulher (Pimentel, 2002).

Podemos partir do princípio de que a família apresentou mudanças de um momento histórico para outro, considerando as culturas diferentes, configuração e papéis desempenhados que vão determinar sua existência. O modo de pensar a socialização das gerações mais novas e o desempenho do papel das mais velhas é hoje muito diverso. Observamos uma grande alteração nos conceitos de criança ideal, de adulto e fundamentalmente da estruturação da família e da relação de seus membros (BIASOLI, 2001).

Há evidências, de que na atualidade, a família tem sido objeto de preocupação na área da enfermagem pelo aumento de estudos sobre a temática. As pesquisas no Brasil sobre família segundo Romanelli (1995) mostram a diversidade na sua organização, na composição e na forma de sociabilidade. Atualmente existem estruturas familiares diferentes coexistindo em nossa sociedade, podemos encontrar cônjuges com filhos de casamentos anteriores, jovens mães solteiras, onde os filhos são cuidados pela avó e pais separados dividindo as despesas e cuidados com os filhos. Essas mudanças ocorridas na composição da família afetam substancialmente a vida doméstica, pois incidem sobre as relações estruturais e redefinem o modelo familiar. 
Marco Teóríco

Camilla Soccio Martins

De acordo com Szymanski (2001) o que se nota, vendo a família urbana de nível socioeconômico baixo numa perspectiva matrifocal, é a mudança de parceiros da mulher, de forma que ela mantém em torno de si o núcleo familiar (ela e os filhos) que não se desfaz com a saída do homem. Ainda é no espaço familiar que são desenvolvidos os valores éticos e humanitários e vínculos de solidariedade, confiança e amor.

Podemos afirmar que o espaço familiar é o meio crítico para o desenvolvimento de uma criança e nele serão construídos e dimensionados os seus valores, limites, educação e o sentimento de pertencimento e significado.

No que se diz respeito às funções da família, Aoki e Tardeli (1994) apontam como sendo quatro: a educacional, a reprodutiva, a sexual e a econômica. A primeira é fundamental para a conservação da cultura, a segunda e a terceira são indispensáveis para a manutenção da sociedade e a última é essencial para a permanência da vida.

O papel a ser assumido pelos membros das famílias, no que diz respeito aos cuidados e à educação dos filhos, dependerá das injunções sociais, econômicas e políticas de uma sociedade, em cada momento histórico.

As possibilidades de definir família são muitas, dependendo da orientação teórica de quem a define. Devemos ainda pontuar que a definição de família é um conceito construído culturalmente e teve muita influência da nova configuração da nossa sociedade e do sistema econômico vigente.

Segundo ainda Szymanski (2001), nem sempre podemos fazer um histórico completo de uma determinada forma de interpretar relações ou 
Marco Teóríco

Camilla Soccio Martins

acontecimentos. As interpretações vão se formando, fixando-se e até modificando-se, é um processo longo, do qual muitas etapas passam despercebidas pela própria pessoa. O importante é tomarmos conhecimento delas e propor-nos a ver outras possibilidades de interpretação dessas relações.

A partir dessa premissa, Taylor (1992) considera uma definição mais acurada e relevante quando reflete as funções da família. Segundo esse aspecto, a autora as fundamenta da seguinte forma: a família é reguladora da atividade sexual e de reprodução, da manutenção física, proteção, educação e socialização, recreação e afeto. Em resumo, estas funções revelam que a unidade familiar oferece serviços essenciais para a sobrevivência e estabilidade da sociedade e seus membros, nos obrigando a considerar uma visão bem ampliada sobre esse grupo.

Atualmente, a família tem sido objeto de preocupação na área da saúde e, em especial, da enfermagem, pelo crescente número de estudos empíricos cujo foco central é a família.

Segundo Ribeiro (2002), a importância da família é valorizada em todas as sociedades, mas historicamente elas não estão se organizando sob os princípios do respeito à pessoa humana, e sim, têm sido organizadas como espaços de hierarquia e subordinação. Algumas funções essenciais da família devem ser revistas nesse intenso processo de transformação e construção da ordem mundial, as causas e conseqüências de violências que incidem nesse espaço devem ser melhor estudadas. 
Marco Teóríco

Camilla Soccio Martins

Não podemos esquecer que depositar na família a responsabilidade única pela conduta de seus indivíduos é uma falha. Concordamos com Biasoli (2001) quando diz que o desenvolvimento e a socialização da criança são subordinados às condições econômicas e sociais em seu contexto mais amplo como explica a Teoria dos Sistemas Ecológicos.

A família, ainda continua, sem dúvida, sendo o espaço indispensável para a garantia da sobrevivência integral dos filhos e demais membros, independente do arranjo familiar ou da forma como vem se estruturando. Enquanto forma específica de agregação, tem uma dinâmica de vida própria, afetada pelo processo de desenvolvimento socioeconômico e pelo impacto da ação do Estado e de suas políticas econômicas e sociais.

O cuidado centrado na família de acordo com Wright e Leahey (2002) já faz parte integrante da prática de enfermagem em âmbito mundial. A família tem papel de extrema relevância nas estratégias preventivas na área da saúde, no planejamento e no cuidado à criança. De uma certa forma, o cuidado centrado na família, envolve todos os seus membros e uma importância especial é dada nas relações estabelecidas entre eles, entendida como um dos determinantes do processo saúde-doença.

\subsection{Violência doméstica}

A questão da violência afetando a sociedade como um todo tem gerado inquietações de âmbito mundial. O fenômeno da violência contra crianças e adolescentes que ocorre majoritariamente na própria família, é considerada uma 
Marco Teóríco

Camilla Soccio Martins

problemática social muito complexa, tanto no que diz respeito à sua etiologia quanto às suas formas de manifestação.

No Brasil, assim como em outras partes do mundo, em diferentes culturas e classes sociais, independente de sexo ou etnia, muitas crianças e adolescentes são vítimas da violência doméstica, sendo este um acontecimento universal e endêmico.

Tratando-se da terminologia empregada para definir violência contra crianças e adolescentes, observamos que muitas definições não abarcam seus contextos familiares, sociais, institucionais entre outros, correndo um sério risco de simplificação do fenômeno. No sentido de evitar essas muitas terminologias usadas incorretamente para conceituar a violência praticada no âmbito familiar, usaremos o termo violência doméstica para designar esses incidentes, pois ela representa o campo temático mais conhecido pela literatura nacional. Deixamos claro também que o conceito de violência doméstica adotado na presente pesquisa se estrutura no contexto doméstico, se amplia nas interações familiares, mas dirige-se essencialmente às crianças e adolescentes.

O fenômeno da violência doméstica ainda traz termos muito utilizados que achamos importante esclarecê-los: vitimação e vitimização. A vitimação enfoca aspectos externos das situações de violência, como condições precárias para o desenvolvimento humano, sendo este de fundo social. Já a vitimização procura suas conseqüências na parte física, biológica e psicológica da criança e do adolescente baseando-se numa visão clínica (FALEIROS; FALEIROS, 2001). 
Marco Teóríco

Camilla Soccio Martins

A violência como conseqüência de ações ou omissões praticadas pelos pais ou responsáveis é uma ocorrência tão antiga quanto a própria história da humanidade. As primeiras alusões à violência contra crianças foram no ano de 1184 a.C. em relatos da mitologia greco-romana, pais que matavam seus filhos eram defendidos e justificáveis (AZEVEDO; GUERRA, 1998).

Dentre esses relatos citamos o mito de Tétis (deusa do Mar), que deixa claro a violência perpetrada de pais contra filhos. A mitologia conta que Tétis, para conseguir a imortalidade, queimava toda noite, às escondidas do pai, seu filho Aquiles e, sobrevindo o dia, curava com ambrósia suas partes queimadas. Outros mitos também fazem alusão à referida violência como o mito de Cronos (Deus do Tempo), filho de Urano (o Céu), e de Géia (Terra), que se revoltou contra o pai, matou-o e tomou seu lugar, a partir de então passou a devorar todos seus filhos à medida que nasciam pois temia que estes o destronariam (AZEVEDO; GUERRA, 1998). Portanto o infanticídio na época era uma prática aceitável e de maneira simbólica através desses sacrifícios é que a sociedade se protegia de sua própria violência, amenizando as tensões nas relações.

Segundo Minayo (2002), a própria Bíblia refere que nos momentos de escassez de alimentação, o povo hebreu comia as crianças mais novas: "Dá cá teu filho para que hoje o comamos e amanhã comeremos meu filho. Cozemos pois, o meu filho, e o comemos".

Um conjunto de mitos e sagas cobre uma área geográfica vastíssima. Santos (2002) dá exemplos de histórias nas civilizações antigas: na Fenícia as crianças eram queimadas vivas e oferecidas aos deuses; no Egito Antigo era 
Marco Teóríco

Camilla Soccio Martins

anual o afogamento de uma criança do sexo feminino no rio Nilo; o pai podia matar e vender seu filho na Grécia e, na China e no Havaí, os pais jogavam o quarto filho às feras para o controle de natalidade.

No período que antecedeu ao século XVIII, surge a utilização dos castigos, da punição física, dos espancamentos em crianças. Justificavam os pensadores da época que os pais deveriam cuidar para que os filhos não recebessem más influências. Na Inglaterra, em 1780, as crianças podiam ser condenadas por qualquer um dos mais de duzentos crimes cuja pena era o enforcamento. Entre 1730 e 1779, metade das pessoas que morreram em Londres tinha menos de cinco anos de idade. Somente no século XIX, o filho passa a ser objeto de investimento afetivo, econômico, educativo e existencial.

Passando para o mundo contemporâneo, o desempenho de papéis sociais nas famílias pode ser indefinido, instável e falho. Romanelli (1995), ao discutir as relações de poder e a autoridade que se estabelecem nas famílias, salienta que um dos atributos básicos da família ainda é o domínio masculino, nascido de forma hierarquizada de poder e autoridade, e que mesmo quando o homem deixa de ser o único provedor doméstico, sua autoridade nunca é eliminada.

A família faz com que a violência objetiva das relações sociais não manifeste diretamente a sua brutalidade, mas que o faça através da interiorização da obediência a um sistema hierárquico e autoritário desde a infância; predispõe, portanto, a agressividade sublimada e reprimida no autoritarismo das relações sociais familiares (CANEVACCI, 1984). O poder do adulto destina-se a socializar a criança, segundo Marques (1994), os pais repetem com os filhos a violência que 
Marco Teóríco

Camilla Soccio Martins

vivenciaram na infância, tornando a violência um padrão repetitivo de comportamento que consideram normal.

Guerra, Santoro, Azevedo (1992) consideram que a violência doméstica é geralmente caracterizada por um abuso do poder disciplinador e coercitivo dos pais ou responsável, em que a vítima é completamente objetificada, e seus direitos fundamentais, como a vida, a liberdade e a segurança, são desrespeitados. De acordo com Deslandes (1994), essa violência traz em si noções cultural e socialmente construídas tais como a noção de proteção à infância, de castigo como instrumento pedagógico, de hierarquia familiar e de dominação do mais forte. Roque (2001) acrescenta que a violência doméstica implica em dominação, exclusão e extermínio da pessoa como direito, tirando sua liberdade física e aniquilando sua identidade moral.

Segundo Belsky (1993), a etiologia da violência de pais contra filhos pode ser compreendida de um âmbito multifatorial interagindo fatores psicológicos, sociais, relacionais e contextuais, relacionados aos próprios pais, às crianças, à dinâmica familiar, à comunidade e à sociedade nos quais estão culturalmente inseridos. Ancoramos nossa pesquisa na relevância desses fatores, uma vez que nosso objeto de estudo é a compreensão dos pais e das vítimas acerca do contexto familiar que por sua vez, de acordo com o nosso referencial ecológico, abrange esses fatores citados acima.

Embora a violência doméstica seja um fenômeno de difícil entendimento pelas controvérsias que geram, podemos classificá-la em suas formas e expressões. Minayo (2002) classifica em quatro principais tipos: violência física, 
Marco Teóríco

Camilla Soccio Martins

violência sexual, violência psicológica e a negligência/abandono, mas de qualquer maneira todos estes tipos são definidos como prática abusiva, transgredindo os direitos de crianças e adolescentes.

No que se diz respeito à violência física, Minayo (2002, p.103) define com "uso da força física contra a criança e o adolescente, causando-Ihes desde uma leve dor, passando por danos e ferimentos de média gravidade, até a tentativa ou execução do homicídio". Segundo Gomes (2002), um dos motivos que estaria associado à dificuldade de denúncia seria a reprodução de padrões culturais, em que se aceita a punição física como medida educativa. Na fase de desenvolvimento, principalmente para as crianças, as práticas educativas dos pais têm grande influência sobre a auto-estima, dependência e motivação de conquista.

Já a violência sexual inclui desde "carinhos especiais", toques constrangedores, até delitos de extrema violência e morte. Ela é definida como qualquer ação de interesse sexual que uma pessoa mais velha tenha para com uma criança (ABRAPIA, 1992). Os crimes sexuais perpetrados contra crianças e adolescentes no âmbito doméstico são de difícil detecção, pois essas situações são veladamente omitidas pelo segredo e silêncio familiar.

Um estudo realizado em uma casa-abrigo na cidade de Ribeirão Preto-SP Martins e Ferriani (2003) identificaram que os agressores são em sua maioria os pais biológicos (50\% dos agressores dos casos estudados) seguido de outros com 37\%, pai adotivo $12 \%$ e padrastro 12,5\%. Esses dados mostram a desestrutura do sistema de apoio familiar dessas crianças e a conivência dos 
Marco Teóríco

Camilla Soccio Martins

progenitores, salienta Ribeiro (2002) em suas pesquisas que as mães quase sempre estão presentes nas residências onde a violência sexual ocorre. A contribuição direta das mães na ocorrência da violência sexual é confirmada através de estudos (AZEVEDO; GUERRA, 1988).

As conseqüências da violência sexual na esfera social são mais percebidas que suas conseqüências físicas e psicológicas. Estão entre elas a dificuldade de aprendizado escolar, dificuldades nas relações socioafetivas, tendência suicida, além de prostituição. Denunciar esse tipo de violência é uma tarefa essencial, uma vez que o silêncio perdoa o agressor e reforça seu poder sobre a vítima.

A forma mais subjetiva de todas elas é a violência psicológica que Minayo (2002, p. 105) define como "quando os adultos sistematicamente depreciam as crianças, bloqueiam seus esforços de auto-estima e realização, ou as ameaçam de abandono e crueldade".

E por fim a negligência "representa uma omissão em relação às obrigações da família e da sociedade de proverem as necessidades físicas e emocionais de uma criança" (MINAYO, 2002, p.106), ela pode estar presente quando os cuidados básicos com a saúde da criança não foram concedidos, quando as condições de higiene que a criança vive são precárias, quando não são fornecidas condições para freqüência escolar da criança ou quando sua alimentação não é adequada.

Essa modalidade de violência abarca questões mais amplas de fundo social e levanta a discussão acerca da distribuição de renda na sociedade, uma vez que recursos na área social podem contribuir para minimizar a negligência. 
Marco Teóríco

Camilla Soccio Martins

Critérios são utilizados para caracterizá-la e um deles diz respeito à cronicidade do ato, ou seja, a ocorrência contínua do fato.

Alguns fatores estão relacionados com a violência doméstica e, segundo Monteiro (2001), elementos estariam sempre presentes e poderiam ser observados nos diversos casos de vitimização: a) a marginalidade social, econômica e social em que se encontram várias famílias; b) a cultura de violência existente no Brasil, favorável à exploração e opressão de uns pelos outros, independentemente da classe social; c) a tendência à coisificação dos filhos pelos pais, que entendem que as crianças e adolescentes são de sua propriedade, cabendo-Ihes, portanto, educá-los da forma que julgarem melhor; d) a idéia de inferioridade das crianças e adolescentes frente aos adultos.

De acordo com Salomon (2002, p.75):

\begin{abstract}
"A habilidade dos pais em cuidar de seus filhos depende enormemente da saúde e dos recursos internos dos pais; entretanto, também é influenciada por sua situação social. A pobreza, o desemprego crônico e a exposição a eventos traumáticos podem prejudicar sua habilidade de orientar e cuidar dos filhos".
\end{abstract}

Focalizando mais especificamente aspectos psicossociais, Bringiotti (1999) afirma que uma relação de violência na infância produz problemas que certamente se manifestarão na relação com outras pessoas. Assim, esses jovens, em relação aos que não sofreram violência doméstica, apresentam um número alto de vínculos inseguros. 
Marco Teóríco

Camilla Soccio Martins

$\mathrm{Na}$ relação com colegas, as crianças vitimizadas tendem a exibir uma maior agressividade e uma menor tolerância à frustração. Portanto, é possível observar condutas anti-sociais nessas crianças, notando-se que essas possuem dificuldades em assumir as perspectivas do outro e discriminar suas emoções. Essas atitudes indicam o quanto pode ser difícil para essas crianças o desenvolvimento de um modelo de relação simétrico baseado no sentimento de igualdade e de confiança, visto que suas experiências são caracterizadas pela exploração, submissão e violação da confiança. Assis (2002) ainda traz que tanto a vítima como o agressor consideram as agressões como algo normal, e até parte integrante do processo de educação. Já sabemos que as noções de direito e respeito aos outros, a própria auto-estima, as maneiras de resolver conflitos, frustrações ou de conquistar objetivos, tolerar perdas, enfim, as maneiras de se portar diante da existência são profundamente influenciadas durante a idade precoce. É assim que muitas crianças abusadas, violentadas ou negligenciadas na infância se tornam agressoras na idade adulta.

O desenvolvimento biopsicossocial da criança e do adolescente encontrase diretamente relacionado à possibilidade de manterem um vínculo familiar estável, nessa perspectiva, a convivência familiar é um aspecto essencial do desenvolvimento de crianças e adolescentes e um direito inalienável destas. Nos ambientes familiares, onde as diversas formas de violência espreitam e se infiltram, a violência doméstica é mais uma peça crucial que interfere e potencializa os problemas no desenvolvimento infantil.(ASSIS, 2002). 
Marco Teóríco

Camilla Soccio Martins

Se analisarmos, sob o plano afetivo, a criança negligenciada, segundo Haim Gruspun (1985), quebrará a disciplina para receber castigo e, em sua fantasia, sentirá que é amada. Esse tipo de atitude das crianças na tentativa de chamar atenção pode ser observado quando as crianças agridem uns aos outros ou os adultos responsáveis por elas.

As análises sobre a violência nos lares, conforme Minayo (2002), mostram que são espaços passíveis de intervenção, pois a violência, sob qualquer ótica, é um fenômeno sócio-histórico-cultural, portanto, construído. Entendemos que o pensar a violência enquanto um fenômeno social implica na necessidade de se conhecer sua trajetória histórica, bem como coloca os profissionais de saúde diante de um amplo leque de possibilidades de intervenção acerca do fenômeno.

\subsection{Política de atenção à criança e ao adolescente}

A origem das instituições atuais destinadas à infância e adolescência remonta à Idade Média. Começamos na Europa no século XVIII, onde a Igreja Católica assumia a incumbência da assistência de crianças e adolescentes pela Irmandade de Misericórdia. Esse tipo de assistência era essencialmente caritativa e o Estado era totalmente isento dessa responsabilidade.

Com a Revolução Industrial e a crescente expansão das cidades surgiram vários problemas de ordem social, entre eles a marginalização de crianças, a criminalidade, a pobreza e a prostituição. Em decorrência de tal situação, os governos e a sociedade da época eram pressionados a criar instituições e política públicas para enfrentar a questão social que ameaçava a ordem pública. 
Marco Teóríco

Camilla Soccio Martins

Segundo Del Priore (1992), nessa mesma época é criada uma instituição que resistiu durante quase meio século, sendo a única de assistência à criança abandonada naquela época. "Roda dos Expostos" assim chamada, devido ao cilindro de madeira localizado na entrada da instituição, onde a criança era deixada por um adulto sem necessidade de identificação deste. Esse tipo de instituição foi inventado na Europa Medieval e foi trazido pelos portugueses durante o período colonial. Essas casas abrigavam crianças até a idade de sete anos completos, ficando depois sob a responsabilidade dos juízes. Essa antiga forma de institucionalização perdurou até meados do século XIX, sendo o Estado isentado de qualquer participação na implantação e no funcionamento desses serviços, pois eram essencialmente caritativos (MERISSE, 1997).

De uma certa maneira, esse tipo de instituição incentivava o abandono de crianças e incitava a irresponsabilidade dos pais, que muitas vezes, deixavam crianças quase mortas na roda como uma forma de omitir da sociedade sua falta de cuidados com os filhos. A cultura da institucionalização permanece ainda nos dias atuais e faz parte das políticas de atendimento à criança e ao adolescente

Com a crescente mortalidade infantil dentro dessas casas pela precariedade dos cuidados prestados e pelas péssimas condições das instalações, os higienistas da época são de tal forma mobilizados e isso redefine decisivamente a imagem da criança na família, sendo esta vista como investimento do Estado. 
Marco Teóríco

Camilla Soccio Martins

Por traz do discurso higienista na época, o que se verifica é que a assistência à criança e ao adolescente representava para o Estado uma forma de continuidade de mão de obra mercantil e de recrutamento militar.

No período colonial, a "Lei do Ventre Livre" em 1871 é sancionada permitindo que os filhos das mulheres escravas a partir de então nasçam livres, mas essa lei representava o interesse das elites econômicas, na medida que os senhores feudais recebiam uma indenização paga em título de renda em troca da criança ao entregá-la para o Estado. O aumento das crianças negras abandonadas na época era significativo e a pobreza era o principal problema relacionado às dificuldades encontradas pelas crianças e adolescentes. As elites pressionavam os governos frente a estas questões sociais e cobravam políticas públicas e criações de instituições (COSTA, 1983).

Almeida (1998) diz que a intervenção da medicina e do Estado sobre a infância no início do século XIX traz importantes mudanças nas organizações familiares e na concepção de criança. No século XX, a criança é entendida como capital humano que o capital industrial precisa para se reproduzir, ganhando uma importância no campo jurídico, social e na medicina.

Segundo o mesmo autor, no início do século $X X$, as instituições marcadamente educacionais começaram a surgir. Aparece a filantropia, desencadeada por profissionais do meio médico e jurídico no assunto da assistência social. Tal estratégia acreditava na intervenção baseada na educação, trabalho e disciplina. Com isso, novas teorias serviram de suporte para a criação 
Marco Teóríco

Camilla Soccio Martins

de projetos, leis e instituições que formam o projeto de assistência social vigorado em todo Brasil. O Estado tornou-se cada vez mais presente na área social.

Todo esse movimento trazia como perspectiva, um tanto quanto contraditória, proteger as crianças e adolescentes e ao mesmo tempo proteger o Estado contra as conseqüências de seu abandono.

Na década de 1980, no que se diz respeito ao campo da saúde pública mundial, surgem os movimentos de prevenção e de atenção especializada em decorrência do reconhecimento da morbimortalidade por violência como um entrave para o desenvolvimento da saúde em seus aspectos sociais, como objeto de atenção primária, secundária e terciária (MINAYO, 2002). Muitos movimentos sociais tiveram papel fundamental na criação de organizações nãogovernamentais - ONGs de atenção à violência na infância, além de organizações internacionais que exerciam influência no Brasil.

Em 1948 a Organização das Nações Unidas - ONU homologa a Declaração Universal dos Direitos Humanos que garante cidadania a todos os homens em igualdade de condições. A Declaração Universal dos Direitos da Criança foi proclamada logo após objetivando a proteção e respeito a essa população, legitimando, pela primeira vez na história, a criança como sujeito de direito.

Na década de 1990, rompendo antigos padrões societários, o Brasil realiza um importante avanço no campo dos direitos humanos, criando o Estatuto da Criança e do Adolescente - ECA, completando atualmente 14 anos. Foi notável a discussão do papel do Estado na infância, passando a ser reconhecido como 
Marco Teóríco

Camilla Soccio Martins

provedor de políticas públicas direcionadas para a necessidade desse grupo populacional. O Estatuto é uma das formas de coibir a violência contra crianças e adolescentes, salientando-se o papel privilegiado da comunidade na garantia dos direitos. A partir de então, as crianças e os adolescentes passaram a ser juridicamente considerados como sujeitos de direitos e não mais como objetos de tutela, de obediência e de submissão (BRASIL, 2001b).

As políticas públicas anteriores priorizavam o atendimento às crianças e aos adolescentes em situação irregular, a atual, se estende a todas as crianças e adolescentes.

O ECA, ao identificar os direitos fundamentais da criança e do adolescente (direito à vida, saúde, liberdade, respeito à dignidade, à convivência familiar, à educação, cultura, lazer), aponta para as condições necessárias para seu desenvolvimento como pessoa. Aponta, também, para a família, como o primeiro lugar onde essas condições devem ser respeitadas. Além disso, pressupõe a família como tendo a possibilidade de prover tais condições (BRASIL, 2001b).

No seio dessas transformações, o Fundo das Nações Unidas para a Infância -UNICEF passou a agendar discussões sobre esse segmento da sociedade, dedicando o ano de 1994 como o Ano Internacional da Família.

Embora essas mudanças ao longo dos anos trouxessem consideráveis avanços, a realidade atual que envolve o atendimento à criança e adolescente vítimas da violência doméstica ainda tem muito a fazer. A dificuldade maior parece residir na operacionalização dos programas que, independentemente das inovações veiculadas, geram resultados nem sempre satisfatórios (SARTI, 1995). 
Marco Teóríco

Camilla Soccio Martins

Na área da saúde, especificamente, a violência doméstica já se apresenta como temática da saúde pública, comprometendo o crescimento e desenvolvimento de crianças e adolescentes. De acordo com Minayo (1994) foi apenas no final da década de 1980 que a temática passou a fazer parte da agenda da Saúde Pública em função do aumento de mortes por causas violentas.

Apesar dos avanços no plano legal, o acolhimento de crianças e adolescentes em instituições, como alternativa de proteção, é ainda freqüente, embora sofra críticas contundentes, pautadas na observação da realidade ainda muito precária das instituições brasileiras. A atuação frente ao cenário emergente da violência doméstica é uma tarefa difícil, mas como poderíamos ficar indiferentes ao problema que vitimiza silenciosamente milhares de crianças e adolescentes anualmente no país?

Concordamos com Vendrúsculo (2004) que coloca em destaque os determinantes econômicos que podem potencializar formas de violência doméstica contra crianças e adolescentes. A fragilização social não determina necessariamente a violência, mas condiciona o desencadeamento de situações de estresse, dependência química, desemprego, promiscuidade entre outros.

Outro problema muito destacado é que a maioria dos casos que chegam aos serviços de saúde não é identificada. Muitos dos atos de violência praticados e testemunhados não são levados ao conhecimento das autoridades, não chegando nem ao menos existir sob a ótica do mundo jurídico (SANTOS, 2002). Os obstáculos para essa situação são muitos e se interligam, mas o entrave que mais se evidencia está relacionado à uma dimensão ética. Vários profissionais 
Marco Teóríco

Camilla Soccio Martins

preferem não se envolver neste tipo de situação que é culturalmente reforçado como um "problema de família", dificultando a possibilidade imediata de intervenção, mas desconhecem o que estabelece o ECA, em se tratando das normas de conduta dos profissionais de saúde, a obrigação da notificação dos maus-tratos conforme artigos 13 e 245 :

Art. 13. Os casos de suspeita ou confirmação de maus- tratos contra criança ou adolescente serão obrigatoriamente comunicados ao Conselho Tutelar da respectiva localidade, sem prejuízo de outras providências legais (BRASIL, 1993).

Art. 245. Deixar o médico, professor ou responsável por estabelecimento de saúde e de ensino fundamental, pré-escola ou creche, de comunicar à autoridade competente os casos de que tenha conhecimento, envolvendo suspeita ou confirmação de maus-tratos contra criança ou adolescente. Pena-multa de três a vinte salários de referência, aplicando-se o dobro em caso de reincidência (BRASIL, 1993).

Dados epidemiológicos são necessários para a detecção, planejamento, execução e avaliação de ações e políticas de saúde voltadas ao atendimento à criança e ao adolescente vitimizados, para isso a notificação compulsória é fundamental para tornar possível o conhecimento de alguns dados a respeito. Deslandes (1994) lembra que a notificação não pode ser encarada como uma última ação para os profissionais de saúde, e sim como uma forma de garantir a continuidade do atendimento à família.

Para fornecer subsídios no reconhecimento, no tratamento e na adequada notificação desses agravos, a Sociedade Brasileira de Pediatria - SBP no intuito de buscar soluções eficazes, elaborou o "Guia de Atuação Frente a Maus-Tratos 
Marco Teóríco

Camilla Soccio Martins

na Infância e na Adolescência" que orienta os profissionais de saúde através de normas técnicas e rotinas, mas ainda assim não existe uma obrigatoriedade do seu uso.

No entanto, a identificação dos casos da violência doméstica é possível nos serviços de saúde desde que sejam fornecidos aos profissionais os devidos conhecimentos e esclarecimento das responsabilidades desse profissional com essas crianças e adolescentes. Salientamos também que qualquer intervenção com as ocorrências de violência na família, bem como pensar a sua prevenção é ter em conta suas especificidades históricas e atuais.

Dessa forma, é papel do setor de saúde liderar ações específicas e de caráter social, implantando programas que prestigiem uma abordagem transdisciplinar e a capacitação desses profissionais, de forma continuada, no intuito de que possam se apropriar de conhecimentos básicos sobre saúde, direitos das crianças, aspectos jurídicos que envolvem os procedimentos judiciais, e atuar de uma forma mais abrangente, evitando intervir sobre um enfoque. Intervenções isoladas, que não valorizem a constante comunicação entre os diversos profissionais, acabam por dificultar a continuidade do atendimento, propiciando, o abandono do tratamento pela vítima e pelo grupo familiar, deixando de lado o abusador. Assis (2002, p.123) acrescenta:

"Os profissionais de diferentes áreas, voluntários, indivíduos das mais diversas origens socioeconômicas que se dedicam ao trabalho de transformar realidades tão violentas em sonhos possíveis podem, hoje, na nossa sociedade, traçar novos caminhos para a criação de políticas mais justas, restituir a autoestima a crianças e jovens e fazer a sociedade pensar sobre o significado da violência" 


\subsection{Pressupostos}

$\mathrm{Na}$ presente pesquisa, buscamos responder às questões ancoradas no nosso objetivo, assim sendo, surgiram os nossos pressupostos, fruto da nossa preocupação enquanto pesquisador.

Pressupomos que as conseqüências da violência incidem sobre todo o núcleo familiar e podem configurar-se no significado de família.

Acreditamos que a violência doméstica está arraigada em um processo denominado ciclo de reprodução da violência, ou seja, que ela gera uma repetição da violência refletindo no cotidiano dessas pessoas.

Tais prerrogativas nos levam a explicitar como os pais e as vítimas da violência doméstica compreendem o significado de família e vislumbrar estratégias de prevenção, encaminhamento e interrupção da violência doméstica. 
PERCURSO METODOLÓGICO 


\section{PERCURSO METODOLÓGICO}

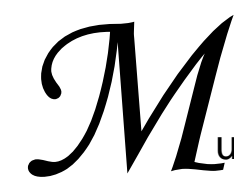

uitas seriam as possibilidades de escolha metodológica para delinear nossa pesquisa. Assim, procuramos escolher uma abordagem que nos permitisse focalizar significados, valores e concepções atribuídos pelas famílias estudadas. Optamos pela abordagem qualitativa que, segundo Wood e Haber (2001), abarca a totalidade dos seres humanos, concentrando-se na experiência humana. 0 pesquisador que usa essa abordagem acredita que seres humanos únicos atribuem significado a suas experiências e que elas derivam do contexto de vida.

A pesquisa qualitativa busca mais que relatar ou quantificar dados, ela parte da observação de uma realidade que não pode ser medida, portanto busca na subjetividade o significado atribuído ao objeto de estudo.

Trivinos (1995) argumenta ainda que a pesquisa qualitativa está impregnada dos significados que o ambiente lhe outorga sendo produto de uma visão subjetiva e que intenta não só a aparência do fenômeno, como também sua essência.

O objeto desse estudo, a compreensão de família para pais e filhos envolvidos na violência doméstica contra crianças e adolescentes, tem a peculiaridade de lidar com a subjetividade dos atores sociais envolvidos e o que é experienciado por eles em suas relações familiares. 
Portanto, é com a perspectiva de produzir um conhecimento, que é parte da realidade, que visualizamos o uso desta análise na nossa pesquisa. Essa opção baseou-se no princípio de que a abordagem qualitativa estabelece uma relação dinâmica entre o mundo real e os atores sociais, entre o mundo objetivo e a subjetividade do sujeito. Minayo (1996) argumenta que os sujeitos sociais que detêm os atributos que pretendemos conhecer perderiam muito do seu significado se fossem abordados quantitativamente.

Vale salientar que a pesquisa qualitativa ainda, para a mesma autora, entende os meandros das relações sociais e afetivas, trabalhando com o universo de significados, crenças e valores, compreendendo e explicando essa dinâmica. $\mathrm{Na}$ enfermagem, a pesquisa qualitativa tem contribuído para o aperfeiçoamento da prática profissional.

\subsection{Campo de estudo}

O campo de estudo é concebido como um recorte que o pesquisador faz, em termos de espaço, em uma realidade social, que vai representar a realidade empírica a ser estudada. Esse recorte espacial é ocupado por pessoas e grupos que convivem numa dinâmica de interação social e são sujeitos de uma determinada história a ser investigada.

Antes de fazermos a apresentação da delimitação do nosso campo de estudo, procuramos rever algumas características da cidade de Ribeirão Preto São Paulo, no sentido de melhor entendermos o espaço em que foram 
desenvolvidas as atividades de pesquisa.

De acordo com o Sistema Estadual De Análise De Dados - SEADE (2002) Ribeirão Preto é localizado na região noroeste do estado de São Paulo, possui uma área total de $651 \mathrm{~km}^{2}$ e uma população de 505.012 habitantes, sendo $97,74 \%$ na zona urbana e $2,26 \%$ na zona rural. A população de crianças, adolescentes e jovens (até 24 anos) representa um percentual considerável da população. No ano de 2000 , eles somavam 217.774 pessoas, cerca de $43,1 \%$ da população.

Os setores industriais e agrícolas, juntamente com amplo setor de serviços e forte comércio, se completam proporcionando um alto padrão de atendimento médico e saneamento somado a um completo serviço de educação, transporte e de comunicação. Sendo um município tipicamente urbano, sua economia está concentrada no setor de bens e serviços.

Na área de educação, há escolas estaduais, municipais e particulares num total de 125 estabelecimentos de ensino fundamental, 46 de ensino médio e cursos de nível superior qualificados, oferecidos por uma universidade pública e seis universidades privadas. (BRASIL/MEC 2000). A rede municipal de creches é composta por 23 unidades que atendem aproximadamente 1.700 crianças na faixa etária de zero a quatro anos, enquanto de quatro a seis anos a pré-escola atende aproximadamente 12.352 crianças.

Entre a população em idade escolar (ensino fundamental), 98\% estão regularmente matriculadas. Entretanto a evasão escolar nessa faixa chega a 27\%, sendo que os principais motivos referem-se à situação socioeconômica da família, 
deficiências pessoais e de saúde (BRASIL/MEC 2000).

As universidades e faculdades existentes no município, concentradas nas áreas de biologia e saúde, torna-se um polo universitário.

Possui uma ampla rede de serviços de saúde que compreende as áreas de atenção primária, secundária e terciária, destacando-se por ser referência para toda a região e para outros estados do país. A rede de saúde do município é formada por serviços estaduais, pela rede municipal, por serviços filantrópicos e particular conveniados.

A rede hospitalar é formada por 10 hospitais gerais, destacando-se o Hospital das Clínicas da Faculdade de Medicina de Ribeirão Preto - H.C. e dois hospitais psiquiátricos. A rede perfaz 1.697 leitos pelo Sistema Único Saúde SUS de um total de 1.960 leitos, onde 95 são leitos da Unidade de Terapia Intensiva - UTI e 175 são leitos de Pronto-Socorro. Cerca de 30\% das internações são de não-residentes, dado que aponta o caráter do município, como Referência Regional da Rede Hospitalar (REDE CRESCER, 2000)

A assistência à saúde está organizada em cinco regiões, denominadas Distritos de Saúde, que possuem suas áreas e populações definidas a partir de aspectos geográficos, econômicos e sociais, que agrupam várias Unidades de Saúde e outros equipamentos sociais. São um total de 27 Unidades Básicas de Saúde - UBSs, 05 Unidades Básicas Distritais de Saúde - UBDSs, 03 Ambulatórios de Saúde Mental.

Os laboratórios clínicos e serviços de apoio abrangem todas as especialidades e são públicos, conveniados e/ou particulares. 
Percurso Metodológíco

Camilla Soccío Martins

Apesar de sua diversidade econômica, enfrenta problemas socioeconômicos, com um número elevado de desemprego. Grande parte da população apresenta um nível social, econômico, cultural e educacional carente o que pressupõe um número elevado de crianças e adolescentes nas ruas e vítimas de todo e qualquer tipo de violência. Para tanto, a cidade ao longo dos anos vem intensificando o atendimento à criança e ao adolescente através de programas e sua implementação.

A assistência da criança e ao adolescente em situação de risco no Município de Ribeirão Preto é implementada e coordenada pela Secretaria Municipal da Cidadania e Desenvolvimento Social. Essa Secretaria foi criada em 1982 e era denominada de Secretaria do Bem-Estar Social, só após a reforma administrativa em 1999 que passou a ser denominada Secretaria da Cidadania e Desenvolvimento Social.

Compete à Secretaria propiciar o desenvolvimento e bem-estar do cidadão por intermédio de programas e serviços socioeducativos e assistenciais, incentivar a participação do cidadão nas políticas públicas, executar a Política Municipal de Assistência Social do Município, desenvolver programas destinados às crianças e aos adolescentes em situação de risco, com orientação familiar entre outras. Seus programas e serviços são divididos por departamentos e seções. Nossa pesquisa se insere na Divisão da Criança e do Adolescente em Situação de Risco. Essa divisão possui programas e serviços tais como: disquecriança, plantão social, programa de apoio e orientação familiar, serviço de recâmbio, família de acolhimento, família substituta, programa de erradicação do 
trabalho de rua, pedagogia de rua, medida socioeducativa e liberdade assistida e os abrigos CACAV (Centro de Atendimento à criança e ao adolescente vitimizado) e a casa travessia (REDE CRESCER, 2000).

O recorte da nossa pesquisa se dá no CACAV, um abrigo para crianças e adolescentes de 02 a 17 anos, vítimas de violência doméstica em risco grave. De acordo com o nosso referencial teórico, o abrigo é considerado o microssistema imediato dessas crianças e adolescentes vitimizados e a partir dele que vão se delineando aspectos relacionais e comportamentais que constrói, em parte, a compreensão acerca da família para estes atores sociais.

\subsection{Seleção dos sujeitos da pesquisa}

Em relação a esse desenho amostral, esclarecemos que, como observa Minayo (1996), em pesquisa social de abordagem qualitativa, a composição da amostra não passa pela representatividade numérica e sim pela representatividade de complexidade do objeto em estudo. Por outro lado, poderá haver sucessivas inclusões de sujeitos até que se possa estabelecer uma análise adequada ao problema.

Os sujeitos envolvidos no estudo foram membros das famílias que possuem criança(s) e/ou adolescente(s) institucionalizado(s) no Centro de Atendimento à Criança e Adolescente Vitimizados (CACAV) no município de Ribeirão Preto-SP, no ano de 2004, por estarem envolvidos nos episódios de violência doméstica. Todos esses atores sociais são de importância central para a 
presente pesquisa, pois cada um representa uma faceta da problemática da violência doméstica aqui estudada. Além disso, levaremos em consideração alguns critérios de inclusão:

a) Consentir em participar da pesquisa, através da assinatura de consentimento livre e esclarecido;

b) Famílias que possuem um dos seus membros institucionalizados no CACAV no ano de 2004;

c) Famílias que possuem vínculo com o abrigo e residem em Ribeirão Preto-SP;

d) Famílias das quais recebem visitas regulares da assistência social;

e) Aprovação pelo Comitê de Ética da Escola de Enfermagem de Ribeirão Preto da Universidade de São Paulo.

\subsection{Técnica de coleta de dados}

No sentido de atingirmos os objetivos referentes à compreensão da dinâmica familiar e seu significado para os atores sociais estudados, elegemos como instrumento de coleta de dados a entrevista semi-estruturada.

A entrevista é um dos principais meios que tem o investigador para realizar a coleta de dados. A entrevista semi-estruturada é aquela que parte de certos questionamentos básicos, apoiados em teoria e hipóteses que interessam à pesquisa e que, em seguida, oferecem amplo campo de interrogativa, fruto de 
novas hipóteses que vão emergindo à medida que recebem as respostas do informante (TRIVINO,1995).

Esse tipo de entrevista com os pais e as crianças envolvidas no episódio da violência doméstica nos permitirá explorar dados relativos à dinâmica familiar da violência e à compreensão dos sujeitos estudados em relação a ela. A partir daí, as questões perguntadas devem ser apenas um ponto de orientação que direcionam a entrevista como um todo. O roteiro da entrevista com os pais e as crianças e adolescentes envolvidos encontra-se em anexo respectivamente (Apêndice A ).

Com o objetivo de garantir o anonimato dos relatos, identificamos as entrevistas dos pais/responsáveis e irmãos das crianças e adolescentes abrigados com a letra F, representando a família. Por sua vez, as entrevistas das crianças e adolescentes abrigados serão identificadas com a letra A.

Procedemos também a uma breve observação de campo que ofereceu dados complementares aos depoimentos.

Concordamos com Bronfebrenner (1996) que deixa claro que a visão e a análise ecológica do microssistema familiar ou do mesossistema dos quais estas crianças e adolescentes dispõem, só podem ser confiáveis se obtidas no próprio ambiente.

As observações serão registradas em um diário de campo. De acordo com Trivinos (1995, p.153) "Observar não é apenas olhar, é destacar de um conjunto (objetos, pessoas, animais, etc) algo especificamente, prestando atenção em suas características". Observar um "fenômeno social" significa, em primeiro lugar, 
que determinado evento social, simples ou complexo, tenha sido abstratamente separado do seu contexto para que, em sua dimensão singular seja estudado em seus atos, atividades, significados, relações, etc. Individualizam-se ou agrupamse os fenômenos dentro de uma realidade que é indivisível, essencialmente para descobrir seus aspectos aparenciais e mais profundos, até captar, se for possível, sua essência numa perspectiva específica e ampla, ao longo do tempo, de contradições, dinamismo, de relações, etc.

Foram alvos de observação: a) ambiente físico, incluindo condições de moradia; b) Ambiente relacional, contemplando a relação entre os profissionais do abrigo e os abrigados e o contato/interação entre os abrigados e suas famílias.

A entrevista foi aplicada pela própria pesquisadora. Esses instrumentos foram testados previamente com crianças e adolescentes abrigados e com seus respectivos responsáveis.

\subsection{Técnica de análise dos dados}

Utilizamos, para o tratamento dos dados, a técnica de análise de conteúdo, modalidade temática, proposta por Bardin (1979). O motivo da escolha de tal técnica se justifica por ser um instrumento de análise que, com maior rigor, analisa o vasto campo das comunicações, facilitando a tentativa exploratória e enriquecendo as interpretações. 
Para Bardin (1979):

\begin{abstract}
"A análise de conteúdo é um conjunto de técnicas visando obter, por procedimentos, sistemáticos e objetivos de descrição do conteúdo das mensagens, que permitam inferência de conhecimentos relativos às condições de produção/recepção dessas mensagens" (p.42).
\end{abstract}

Dentro do vasto campo da técnica de análise do conteúdo, elegemos a modalidade temática para interpretar as mensagens contidas nas entrevistas. Essa modalidade, segundo o mesmo autor, consiste na contagem de um ou vários temas ou itens de significação, numa unidade de codificação previamente determinada. O tema, na verdade se define como sendo: "Uma unidade de significação complexa que se liberta naturalmente de um texto analisado segundo certos critérios relativos à teoria que serve de guia `a leitura" (p.105) (BARDIN, 1979). Ainda temos que essa análise enxerga por trás dos conteúdos manifestos, indo além das aparências do que está sendo comunicado. (GOMES, 2001).

A análise temática organiza-se em volta de um processo de categorização que é uma operação de classificação de elementos constitutivos de um conjunto, por diferenciação e, seguidamente por reagrupamento segundo o gênero (analogia), com os critérios previamente definidos. As categorias reúnem um grupo de elementos (unidades de registro, no caso da análise de conteúdo) sob um título genérico, agrupando esse efetuado em razão dos caracteres comuns desses elementos ( BARDIN, 1979).

No sentido de melhor organizar e explorar os resultados obtidos na nossa pesquisa, utilizamos uma seqüência de etapas propostas por Bardin e citadas por 
Minayo (1999) na análise de conteúdo:

1. Pré-análise: essa fase consistiu basicamente em sistematizar as idéias iniciais, ou seja, um plano de análise. Esse plano começou com a organização do material disponível para a análise, no caso, as entrevistas.

Realizamos primeiramente a transcrição das fitas com as entrevistas que foram gravadas individualmente, logo após iniciamos com a leitura flutuante. Esse tipo de leitura permitiu analisar e conhecer o discurso das entrevistas que pouco a pouco vai se tornando mais preciso em decorrência dos pressupostos emergentes.

2. Exploração do material: baseou-se na transformação dos dados em conteúdos temáticos através da codificação das entrevistas, determinando, assim, as temáticas que serão discutidas. Essa determinação foi alicerçada em observações realizadas e na fundamentação teórica que propusemos. Os dados foram agrupados em basicamente duas temáticas.

3. Tratamento dos resultados, inferência e interpretação: através dos resultados obtidos nas fases anteriores, utilizamos inferências e interpretações a partir da fundamentação teórica e dos pressupostos que nortearam esta investigação. 


\subsection{Aspectos éticos}

Esta pesquisa se integra em um dos subprojetos do Projeto Temático que obteve aprovação do Comitê de Ética em pesquisa da Escola de Enfermagem de Ribeirão Preto-USP no protocolo nº 0120/2000 (Anexo).

Para o desenvolvimento do estudo foi enviada à instituição pesquisada a solicitação de autorização, com cópia do projeto em anexo.

Os atores desta investigação, de acordo com a resolução 196 de 1996 do Conselho Nacional de Saúde devem concordar em participar da pesquisa após serem esclarecidos sobre os objetivos da pesquisa e ter-Ihes sido garantido o direito de anonimato e confidencialidade dos dados, além de estarem cientes do termo de consentimento livre e esclarecido para pesquisas científicas em seres humanos (Apêndice B). Só foram utilizadas neste estudo as entrevistas devidamente autorizadas. 
RESUL'TADOS 


\section{RESULTADOS}

\subsection{Caracterização do campo de estudo}

Inserimos a caracterização do nosso campo de estudo nos resultados pois segundo o nosso referencial teórico, o contexto ambiental é entendido como um microssistema ecológico que influencia e é influenciado por aspectos desenvolvimentais, comportamentais e relacionais das crianças, adolescentes e seus familiares.

De forma específica, o CACAV recebe a demanda de crianças e adolescentes encaminhados pelo Conselho Tutelar após a confirmação da "existência de situações de risco ao desenvolvimento pessoal e social desses jovens, tal como abandono, orfandade, maus-tratos, violência intrafamiliar, etc.“ (Estatuto da Criança e do Adolescente - ECA, Art. 98). O processo de atendimento começa a partir de uma denúncia ou solicitação de ajuda realizada por qualquer pessoa, caso haja risco para crianças e adolescentes, o Conselho Tutelar é acionado.

O Conselho Tutelar é um órgão público municipal criado por lei, composto por cinco membros escolhidos pela comunidade local para um mandato de três anos e tem como objetivo fazer cumprir os preceitos do ECA. Ele é permanente, autônomo e não jurisdicional, ou seja, não se integra ao poder judiciário, mas está subordinado ao ordenamento jurídico do País e apenas a Justiça da Infância e da Juventude pode reavaliar as decisões tomadas por ele (RIBEIRO, 2002). 
Constatada a necessidade de retirar a criança e/ou adolescente da responsabilidade da família, estes são encaminhados através do Conselho Tutelar ao CACAV onde permanecerão provisoriamente.

O CACAV possui capacidade para 60 abrigados, a clientela atendida caracteriza-se por crianças e adolescentes de 02 a 17 anos que sejam encaminhados formalmente através de Conselhos Tutelares e Juizado da Infância e Juventude, de ambos os sexos, em condições de abandono, carentes de cuidados básicos, vítimas de abuso físico, emocional e sexual.

A institucionalização de crianças e adolescentes é uma forma de expressão da violência estrutural definida como "aquela que incide sobre a condição de vida das crianças e adolescentes, a partir de decisões histórico econômicas e sociais, tornando vulnerável o seu crescimento e desenvolvimento." (MINAYO, 2002, p.99). Considerando esse aspecto, a finalidade do CACAV é oferecer à criança e ao adolescente um abrigo que atenda às necessidades amplas no sentido provisório baseado nos princípios propostos pelo ECA no Art. 92 que são: preservação dos vínculos familiares; não-desmembramento de grupos de irmãos e evitar sempre que possível a transferência para outras instituições de crianças e adolescentes abrigados. Os objetivos vão se implementando ao longo da permanência da criança e do adolescente no CACAV, visando sempre ao retorno ao lar e à reestruturação das famílias, embora isto nem sempre seja possível.

Em geral, são feitas todas as manobras possíveis para reabilitar a família para que essas crianças e adolescentes voltem para casa; se não conseguirem a reabilitação da família de origem tentarão com outros familiares ou pessoas 
próximas e estes ficam com a guarda ou tutela provisória/definitiva dessas crianças, estas são as chamadas famílias substitutas. Se não houver uma família substituta, essas crianças vão para o cadastro das adoções. Para que ocorra a adoção, deverá haver a destituição do poder familiar dos pais. No Brasil culturalmente não se adotam crianças acima de cinco anos de idade, em geral as famílias preferem bebês, pois consideram que estes ainda não sofreram influência social de outros ambientes familiares.

O retorno à família de origem, a adaptação à família substituta e a adoção quando ocorre são acompanhados de forma sistemática pela equipe do abrigo.

Com a resolução do caso na Vara da Infância e Juventude, a criança e/ou adolescente volta para sua família biológica, pode ser encaminhada para uma família substituta guardiã, pode ser adotada ou ainda, pode permanecer no abrigo até completar 18 anos.

Entende-se como família substituta e guardiã aquela que se propõe a trazer para dentro de sua própria casa, uma criança ou adolescente que, por qualquer circunstância, foi desprovido da convivência com a família natural, para que seja parte integrante dela, e nela se desenvolva, estando sujeita aos mesmos direitos e deveres que a família natural possui (DAHER, 2003).

A família substituta e guardiã é regida pelo Estatuto da Criança e do Adolescente (ECA) sob a Lei 8069 de 13.07.1990 e pelo Código Civil, no caso de jovens com idade entre 18 e 21 anos. De acordo com Diniz (2002), esta família tem necessariamente que possuir a guarda da criança ou adolescente. Pela lei N.8069/90, Art. 28 do Código Civil, constitui guarda um meio de colocar a criança 
Resultados

Camilla Soccio Martins

e o adolescente em família substituta ou em associação, independentemente de sua situação jurídica, até que se resolva, definitivamente, o destino deste. Esta família pode ainda, depois da decisão judicial da criança, no caso dela ser retirada do poder famíliar, requerer a tutela ${ }^{1}$ ou adoção ${ }^{2}$ deixando de ser família substituta.

A vantagem da família substituta sobre o abrigo é que ela teoricamente oferece um lar convencional, resgatando referências a valores familiares, a figura do pai, da mãe e dos irmãos.

Após a resolução, o período médio de acompanhamento das crianças seja ela na família biológica ou na substituta pelas assistentes sociais é de 6 meses, favorecendo o vínculo entre profissionais e a família.

No que se diz respeito à estrutura organizacional e recursos humanos, o abrigo dispõe de um quadro de funcionários composto por 28 da rede pública e contratados particulares, sendo eles: 16 educadores, 6 auxiliares de serviço (lavanderia e limpeza), 2 cozinheiras, 2 assistentes sociais, 1 psicóloga, 1 terapeuta ocupacional, 2 encarregadas de outras funções, 1 técnico de enfermagem, 3 coordenadores e 1 guarda-noturno. Os educadores dão assistência às crianças e adolescentes no sentido de observá-los, exigir os cuidados com a higiene pessoal, controlar os horários das refeições e comandar atividades educativas e recreativas. Todas as crianças que ali permanecem estão

\footnotetext{
${ }^{1}$ Tutela: é um complexo de direitos e obrigações conferidos pela lei a um terceiro, para que proteja a criança e/ou adolescente que não se acha sob o poder familiar e administre os seus bens.

${ }^{2}$ Adoção: a adoção vem a ser o ato jurídico solene pelo qual, observados os requisitos legais, alguém estabelece, independentemente de qualquer relação de parentesco consangüíneo ou afim, um vínculo fictício de filiação, trazendo para sua família, na condição de filho, pessoa que geralmente lhe é estranha.
} 
matriculadas em pré-escolas e escolas e são acompanhadas por terapeuta ocupacional, psicóloga e assistente social. A assistência médica é realizada através da rede pública de saúde.

Há grupos semanais de pais. Nestes encontros, os temas são propostos pelos pais. Os grupos são informais, nos quais são utilizadas técnicas que visem dinamizá-los. O objetivo do grupo é a conscientização da violência praticada pelos pais. A enfermagem, neste cenário, é de fundamental importância na orientação para que não ocorra a revitimização dessas crianças e adolescentes caso eles voltem para seu núcleo familiar de origem.

Quanto ao espaço físico, este ainda é provisório, localizam-se em uma casa alugada de alguns cômodos e um quintal muito limitado. Por falta de espaço físico, algumas atividades de recreação ficam prejudicadas.

Entendemos que o ambiente imediato dessas crianças e adolescentes contribui para uma compreensão mais sistêmica do contexto da violência doméstica sob a ótica desses atores sociais, uma vez que a institucionalização reflete na maneira como estes percebem suas famílias. 


\subsection{Caracterização dos atores sociais}

primeiro segmento de atores sociais estudados se refere aos adolescentes e crianças abrigadas (A). O critério para a classificação de crianças e adolescentes segundo a idade, foi utilizado o estabelecido pelo Estatuto da Criança e do Adolescente ( Brasil, 1993) que denomina ser criança o indivíduo com idade até doze anos incompletos e, adolescente, aquele entre 12 e 18 anos de idade.

Considerando o exposto, nossos sujeitos são crianças e adolescentes entre 8 a 16 anos de idade, perfazendo um total de oito vítimas, apenas duas são crianças e seis são adolescentes, fato que Reis (2001); Roque (2001); Ribeiro (2002) observam, em suas pesquisas, o contrário, ou seja, que crianças, e não adolescentes, apresentam o contingente que mais é denunciado aos órgãos competentes por agressões dentro da família.

A atual pesquisa revela que as vítimas são em sua maioria do sexo masculino e apenas uma do sexo feminino, de um total de oito. Esses achados pode ter sua justificativa no fato de que no abrigo, em geral, encontramos mais vítimas do sexo masculino. Sadigursky apud Ribeiro (2002) aponta que a violência cometida contra o sexo masculino por um agressor masculino denota a 
expressividade do poder em forma de hierarquia e domínio sobre a vítima masculina.

Quanto à escolaridade, todas essas crianças e adolescentes estão matriculados em escolas públicas, fato que Bronfenbrenner (1996) concebe como um fator de proteção. Isso se explica pelo fato de que quando a criança e o adolescente encontram-se inseridos em um sistema ecológico mais amplo, no caso do mesossistema escolar, eles desenvolvem habilidades sociais e estabelecem vínculos com outras crianças e até mesmo com os cuidadores/professores, gerando e promovendo quase sempre a resiliência.

Embora a escola possa representar um ambiente desenvolvimental do ponto de vista ecológico, notamos a tendência dos abrigados a desenvolverem problemas de adaptação escolar. Entre as oito crianças e adolescentes abrigados, quatro apresentavam problemas escolares tais como: agressividade com os outros alunos e professores, comportamentos sexuais inadequados, resistência às regras impostas pela escola e dificuldade de aprendizagem e atenção.

Tal situação parece constatar nosso pressuposto de que a violência experienciada pode Ter sua reprodução na vida cotidiana dessas pessoas.

Podemos dizer, ainda, que o ambiente escolar é um meio propício para se atuar no sentido de prevenir todo e qualquer tipo de violência, mas a realidade nos mostra quase que o contrário, como salienta Vendrúsculo (2004). A escola, muitas vezes, atua como reforçador da violência em relação à criança, enquanto 
tenta negar e excluir a violência produzida pelo meio social. Tal fato contribui para que a escola perca seu papel de educadora transformando-se em um espaço, muitas vezes, produtor de violência.

Outra característica apontada pelo nosso estudo foi o tempo de abrigamento de cada criança e adolescente uma vez que isso pode acarretar em um processo de desvinculamento familiar cada vez maior, ou seja, no distanciamento da família como contexto ambiental. Considerando o caráter temporário do abrigamento, a permanência prolongada representa não só a dificuldade de reestruturação familiar como a complexidade da resolução, perante a justiça, de casos de violência confirmados.

Nesse sentido podemos observar que o tempo médio em que os atores sociais de nossa pesquisa ainda estavam abrigados, até então, variou de dois a nove meses em quatro famílias e em duas famílias esse tempo foi superior a dois anos, chegando a cinco anos, fazendo com que o abrigo perca seu caráter provisório.

A reinserção dessa criança e adolescente na família de origem é entendida como prioritária na resolução dos casos, uma vez que todas as manobras são feitas no sentido de restaurar funcionalmente essa família e reintegrar suas vítimas, concomitante ao um amplo processo de fiscalização pela assistência social. A realidade dentro das famílias nos mostra que nem sempre isso é possível. Muitas tentativas de reinserção acabam sendo infrutíferas e como conseqüência trazem a revitimização e o reabrigamento. Em nossa atual 
pesquisa, encontramos dois casos de revitimização em duas famílias. A literatura através de Reppold (2002) traz que o risco de uma criança ou adolescente que foram vítimas da violência doméstica sofrerem uma revitimização é cerca de 70\%, ou seja, dificilmente a violência ocorre uma vez só.

Segundo observado neste estudo, identificamos também que a única adolescente do sexo feminino que fez parte da nossa pesquisa foi vítima de violência sexual na infância e atualmente é mãe, tendo engravidado aos 14 anos de idade.

Dados de um levantamento realizado por Heise apud Ribeiro( 2002) vêm ao encontro com os nossos onde foi observado dentro de um hospital internacional que $90 \%$ das mães adolescentes grávidas entre a idade de 12 a 16 anos sofreram abuso sexual pelos pais biológicos, padrastos ou parentes próximos.

O segundo segmento de atores sociais refere-se aos familiares responsáveis legais pelos abrigados, sendo alguns deles os próprios agressores. Essa categoria será representada pela letra (F). Desses atores, foram entrevistados duas mães, dois pais, três tias, uma irmã e uma madrasta distribuídos em seis famílias (Apêndice C).

A família não pode ser vista como uma unidade isolada do contexto social independentemente de sua composição, no entanto, concordamos com Reppold (2002) que traz a reflexão de que os fatores de risco mais importantes para a negligência são: o tamanho da família, a falta de apoio social e a vivência em uma 
comunidade pobre. De fato, a sexta família citada em nossos estudos que negligenciou seus seis filhos é uma família numerosa vivendo em condições de pobreza, entretanto devemos considerar que são fatores predisponentes para a negligência e não fatores que realmente promovem esse tipo de violência.

A maior parte das famílias é composta por uniões informais. Muitos são os fatores que têm favorecido um aumento significativo de uniões informais. De acordo com Roque (2001), em nossa realidade brasileira é evidente o aumento de crianças e adolescentes residindo com mães e padrastos e pai com madrastas. De fato, encontramos uma proporção grande de famílias recompostas com a presença de filhos de uniões anteriores.

Considerando o exposto, apontamos, nesta pesquisa, para a prevalência de núcleos familiares compostos por parentes próximos como tios e tias em decorrência do falecimento dos pais.

Observamos também que uma das famílias é chefiada exclusivamente pela mulher. Essa característica mostra-se coerente com a realidade brasileira, consolidada pelas mudanças aceleradas nos costumes e pela crise econômica das últimas décadas.

Destacamos ainda que o falecimento dos pais em três das famílias foi em decorrência de serem portadores do vírus HIV e pelo uso e abuso de drogas e álcool.

O uso e abuso de álcool e drogas pelos pais agressores é evidenciado através dos relatos das crianças e adolescentes abrigados. Na verdade podemos 
dizer que essa questão não é responsável direto mas desencadeante do processo da vitimização.

Tal análise vem ao encontro com dados de uma outra pesquisa que desenvolvemos sobre a caracterização dos agressores sexuais de crianças e adolescentes, onde Martins e Ferriani (2002) ressaltam que a maioria dos agressores sexuais eram alcoólatras. Entende-se que a violência não é conseqüência do uso de álcool, mas o alcoolismo aparece como agente facilitador da violência uma vez que a predisposição para esta já existe.

As condições econômicas dos familiares das crianças e adolescentes apontam que a renda familiar é de, em geral, dois salários mínimos. Podemos comparar com a pesquisa de Roque (2001) que aponta que 54,2\% das famílias praticantes da violência contra a criança viviam em média com um a três salários mínimos.

A violência estrutural dessas famílias refletidas na dificuldade financeira, no desemprego e na exclusão social são fatores presentes de acordo com a nossa observação de campo.

Minayo e Souza (2002) conceituam a Violência Estrutural como um tipo de violência que está, de uma forma complexa, arraigada em todos os demais tipos, e é caracterizada como aquela que resulta das decisões históricoeconômicas e sociais do Estado, determinando e produzindo exclusão.

O problema do desemprego foi constatado na maioria das famílias estudadas, gerando uma situação de insatisfação e estress que pode ter sido 
Resultados

Camilla Soccio Martins

responsável pelo desencadeamento da violência. Assim, como propõe nosso referencial, o exossistema - ambiente do qual a criança e o adolescente não participam ativamente - pode influenciar o microssistema familiar.

Encontramos em diferentes pesquisas (ROQUE, 2001; VENDRÚSCOLO, 2004; IOSSI, 2004) que a maioria dos agressores estavam desempregados.

A pobreza não é o único determinante da violência estrutural dessas famílias. Botelho (2004) considera que existe um processo de fragilização social que acaba por culminar na privação de alimentação, condições precárias de moradias, desemprego e alcoolismo levando à relações violentas.

De acordo com os dados da nossa pesquisa, podemos observar que os tipos de violência mais freqüentes nas famílias das crianças e adolescentes abrigados têm sido: negligência em sua maioria, violência física e violência sexual. Considerando que em duas famílias a associação dessas violências mostrou-se evidente.

Entre as seis famílias, conseguimos entrevistar os agressores da violência doméstica perpetrada em quatro delas, dessas quatro famílias, dois dos agressores eram os pais biológicos. Parece evidente que os agressores estão dentro dos lares, denotando que a violência independe de vínculos com o agressor. Semelhante a esses resultados, temos um estudo realizado por Reis (2001) que afirma que muitas das crianças e adolescentes que sofreram violência doméstica conheciam seus agressores e em sua maioria eram os pais biológicos e padrastos. 
Assim, de acordo com os dados, o pai aparece como principal agente na violência doméstica. Encontramos semelhante dado em uma pesquisa realizada por lossi (2004), no município de Guarulhos, onde o pai é o responsável pela violência, seja ela física, sexual ou negligência.

Salientamos, que através desses achados, fica evidente as relações de poder e gênero que embasam os valores e prerrogativas culturais definindo o papel do homem na sociedade traduzido pela superioridade, pela força e dominação.

Dentro desse processo de relação de poder, temos na literatura o que alguns autores chamam de "síndrome do pequeno poder" onde o pai, desprovido do macropoder que encontra-se concentrado nas mãos daqueles com alta concentração de renda, chega do trabalho, humilhado e insatisfeito, exercendo exageradamente seu micropoder espancando seus filhos e esposa. As crianças e adolescentes por sua vez estão quase sempre no final dessa cadeia de relações estabelecidas através da síndrome do pequeno poder. Recaem contra elas os desentendimentos do pai no trabalho, as humilhações sofridas pela mãe e até a insatisfação do professor em relação à escola. Ë através de abusos e torturas que esse pequeno poder se evidencia (AZEVEDO; GUERRA, 1989).

Esclarecemos que, a partir desse cenário descrito, as dimensões da violência se traduzem em diversos aspectos, intervindo negativamente no crescimento e desenvolvimento dessas crianças e adolescentes. 
E ainda, salientamos que, para entender a criança, no seu cotidiano familiar, não podemos pensá-la fora do contexto social, histórico, cultural e material em que ela está inserida e isso implica conhecer seus modos de vida, sua organização familiar e as práticas educativas as quais é submetida.

\subsection{Núcleos Temáticos}

\subsubsection{Núcleo Temático 1}

\section{O contexto familiar}

$\mathrm{Na}$ tentativa de elucidar a dimensão e a complexidade do tema abordado através das falas dos sujeitos entrevistados, este núcleo configurou-se em três subtemas: Família Ideal, Família Real e Abrigamento Esses subtemas foram construídos a partir das significações dos discursos dos atores envolvidos. 


\section{Subtema 1 - Família Ideal}

A família tem um papel determinante na manutenção da ordem social, através da estrutura do espaço social e suas relações. Definir família é um trabalho muito complexo e depende das experiências de cada pessoa em seu contexto individual, social e relacional.

O conceito de família definida pelos atores sociais pode ser um referencial imposto pelo ambiente exterior do indivíduo ou pode ser produto de uma construção própria de sua história. Portanto, as análises que se seguem contemplarão uma multiplicidade de experiências vividas.

No que se diz respeito à configuração familiar, predominou a visão entre os pais e responsáveis pelas crianças e adolescentes abrigados, a família nuclear, ou seja, a idealização de uma família vinculada aos pais biológicos e laços consangüíneos. Destaca-se também a existência de uma relação hierárquica deles sobre os filhos. Szymanski (1997) através de um estudo com famílias brasileiras de baixa renda contatou que o modelo idealizado de família é aquele baseado no parentesco, na família nuclear burguesa onde predomina a estrutura do pai, mãe e filhos. Somente este modelo é capaz de prover as condições necessárias para o desenvolvimento de uma criança. Notamos isso nas citações abaixo: 


$$
\begin{aligned}
& \text { “Um conjunto de pessoas que tem algum vínculo } \\
& \text { sangüíneo"( F5). }
\end{aligned}
$$

Embora tenham ocorrido mudanças significativas nas últimas décadas em relação à composição familiar, essas pessoas ainda entendem família através de uma visão nuclear o que não deixa de ser um aspecto que ainda permanece social e culturalmente estabelecido em nossa sociedade. O modelo de família nuclear ainda é idealizado no imaginário social da família ocidental, apesar das certezas e definições acerca dessa instituição terem sido abaladas. Assim, essa idealização pode ser compreendida como uma forma de proteção contra o sofrimento advindo da violência.

Já, a maioria das crianças e adolescentes considera como membros de sua família aquelas pelas quais nutrem algum sentimento de afeição e de confiança, estando vinculada mais ao sentimento de amor do que a laços de sangue. As falas seguintes mostram isso:

“..eu nem sei se eu consideraria minha mãe como minha mãe e pai eu nunca tive" (F1).

"Considero minha família todos que me ajudam, que ainda tem uma esperança por mim" (A1). 
"Pessoas com quem eu convivo eu também considero como irmão, como as pessoas aqui do abrigo" (A4).

De acordo com as nossas observações, podemos dizer que em decorrência da violência doméstica ou pelo fato de estarem institucionalizados provisoriamente, as crianças e adolescentes constróem uma determinada visão sobre família fundamentada em uma perspectiva ecológica e psicológica.

Essas definições vão ao encontro com a literatura onde De antoni (2000) deixa claro que crianças e adolescentes vitimizadas pelos pais consideram, como membros da sua família, as pessoas com as quais têm alguma proximidade afetiva do que aquelas com quem têm apenas laços de consangüinidade.

Portanto essa visões relatadas de configurações familiares, demonstram a compreensão do microssistema familiar conforme a definição de família, sugerida pela perspectiva ecológica (BRONFENBRENNER, 1996). A família é compreendida a partir de um ambiente no qual existem relações de afeto, reciprocidade e proximidade.

A constituição familiar é representada por pessoas significativas com as quais possuem relação de apoio e troca. Esta maneira de enxergar a família pode representar uma forma de proteção, uma vez que permite ampliar a rede de apoio pertencente ao microssistema familiar, que vai além do grau de parentesco. 
Crianças e adolescentes que sofreram algum tipo de violência doméstica relacionam a composição familiar com a qualidade de relações estabelecidas entre as pessoas que são consideradas como membros da família, podendo ser fruto das relações conflituosas experienciadas.

Quanto à função da família, tanto as crianças e adolescentes como seus pais e responsáveis carregam consigo uma carga de expectativas. Esperam que ela seja capaz de fornecer todo um aparato afetivo e social para o desenvolvimento dos seus membros a nível do macro e microssistema, a família é vista como uma instituição sólida e saudável. Isso pode ser evidenciado nas falas que selecionamos:

“... é o alicerce para a criança, o jovem e o adulto de amanhã..."( F1)

“..família é união, é amor, é carinho, é compreensão e respeito..." (F3)

“..educação, amor. É o máximo que nós podemos tirarmos de nós e darmos para uma criança..."(F6) 
A complexa situação de crise social e econômica pode provocar modificações nos padrões sociais aceitos pelas pessoas, particularmente nas identificações de família. Podemos evidenciar isso na fala abaixo:

“Eu queria ter uma família como era antes, meu pai era rico e eu tinha bicicleta e o papai Noel foi lá em casa e levou duas caixas de bolacha" (A6).

A relação de bens materiais com o conceito de família podem ser explicados no contexto da institucionalização, onde muitos dos casos de abrigamento têm como pano de fundo dificuldades financeiras, que findam por determinar a própria dissolução da unidade familiar.

A idealização dos papéis dos pais quando estes estão ausentes também é um fator marcante. Percebemos que a institucionalização, de alguma forma e em algumas situações, contribui para preservar uma imagem de pais compreensivos e cuidadosos. Há uma necessidade constante das crianças e adolescentes de valorizar as pessoas ausentes.

Essa situação pode desencadear fatores de risco, no sentido de que essas crianças e adolescentes depositam expectativas de uma relação com os pais que só existe na esfera do ideal. Tal fato impede que essas crianças e adolescentes enfrentem a realidade negligente e violenta de sua família. 
“..eu to sentindo muita falta dela, ela foi uma ótima mãe pra $\operatorname{mim} "(A 3)$.

“..e agora, todo dia quando eu vou dormir a primeira coisa que eu sonho mesmo é com meu pai, eu sonho que estou com eles novamente" (A6).

“Nós não temos problemas na convivência familiar, não tem atrito e nem briga" (A4).

"Meu pai e minha mãe era boa gente" (A4).

Ao confrontarmos os depoimentos desses atores sociais com a literatura revisada, encontramos aspectos semelhantes quando De antoni (2000) relata ser provável que essas crianças idealizem a figura dos pais para evitar o sofrimento causado pela realidade de abandono em que vivem em função da institucionalização, e para nutrir um sentimento de esperança de que alguém os ama e que poderá modificar sua situação de vida.

Outro enfoque que vale ressaltar é a visão, de uma perspectiva ideal, de como os filhos deveriam ser educados pelos pais. A maioria dos discursos tanto 
das crianças como dos adultos gira em torno de que a melhor maneira de educar os filhos é através do diálogo onde a agressão física nunca deveria estar presente.

Este fato pode ser indicador de proteção ao favorecer estas famílias a repensar suas atitudes sobre a disciplina a ser adotada na criação de seus filhos, uma vez que já foram agressores e vítimas em potencial.

Para as crianças, há uma expectativa em relação à maneira de disciplinar e de educar seus futuros filhos. Notamos a necessidade de romper com o modelo educacional praticado pelos pais. A princípio, condenam a punição corporal e mencionam o desejo de adotar outras formas disciplinares como o diálogo e a punição restritiva.

"Eu trataria meus filhos muito diferente da minha mãe, totalmente. Seria muito atenciosa"(F1).

O conhecimento sobre a situação experienciada de violência por seus antecedentes poderá ser um indicador de proteção, pois poderá evitar a violência doméstica, proporcionando o rompimento do ciclo da transmissão intergeracional da violência (BELSKY, 1993). 
As expectativas referem-se à necessidade e desejo de constituírem uma família e possuir bens materiais. A vontade de romper com a violência doméstica, almejando uma qualidade de vida melhor também foi citada.

‘Queria ter uma casinha pra mim, arrumar um serviço e trabalhar pra mim poder ficar com a minha filha" (A5).

"Quando eu tiver 21 anos e eu tiver trabalhando vou pôr dinheiro pros meus filhos no banco" (A6).

Fica claro a expectativa dessas crianças depositada na auto-estima e na dignidade de possuir um emprego e assim romper com a cadeia da violência. Essa questão parece emergir com a situação vivenciada através do desemprego do pai e das humilhações decorrentes da falta de dinheiro, de moradia e de alimentação. A dinâmica da violência assume um aspecto macroestrutural onde as desigualdades sociais, o desemprego, a exclusão social e moral, a corrupção e a impunidade são fatores que predeterminam o fenômeno. Aprofundaremos mais essa questão no próximo núcleo temático.

\section{Subtema 2-família Real}

Apesar de todas as transformações que traduzem a diversidade da família na atualidade, permanecem vivas, ainda, no imaginário social, expectativas e 
idealizações dirigidas à família. Espera-se que a família seja capaz de produzir cuidados e proteção, acredita-se também que ela seja capaz de construir identidade e vínculos de pertencimento entre seus membros, entretanto, quando observamos as relações interpessoais das famílias em estudo, a idéia inicial da família ideal é logo substituída por uma visão que está de acordo com a dura realidade da violência submetida.

As crianças e adolescentes afirmaram, no subtema anterior, que a família representava união e fonte de carinho. Nos discursos, podemos apreender que o microssistema familiar se caracteriza pela presença de situações de perda, abandono, afastamento e abuso.

Essa constatação vai ao encontro do nosso pressuposto em que as conseqüências da violência configuram-se no significado de família real, embora, observamos que no núcleo temático anterior a família ideal é percebida fora do contexto da violência.

Em nossos achados, observamos uma considerável dificuldade em relação à autoridade nas inter-relações familiares. A figura da mãe não consegue impor autoridade e colocar limites, cabendo isto ao pai que por sua vez pode não estar presente para exercê-la, fazendo com que o microssistema familiar da criança seja deficiente no que se diz respeito à colocação de limites.

Concordamos com Romanelli (1995) quando afirma que a família atualmente se estrutura de forma hierarquizada e paternalista, onde o homem exerce o poder sobre a esposa e os filhos. 
"Eu não tenho culpa dele ser rebelde, a culpa é do pai dele que não educa ele direito" (F2).

A relação de poder estabelecida entre irmãos é outro aspecto bem mencionado. Essa relação é percebida no contexto do controle e comando que os irmãos mais velhos exercem sobre os mais novos. Esta idéia de poder faz parte do macrossistema e influencia os demais contextos, principalmente o microssistema familiar, podendo ocasionar conflitos, comportamentos agressivos e sentimentos de submissão e rejeição. Esse comportamento pode estar baseado na necessidade de resgatar uma figura que represente autoridade na ausência dos pais. Outra explicação para tal fato reside no pressuposto da reprodução da violência:

“..eu erro muito com os meus irmãos porque eu não falo três vezes, na primeira eu falo e na segunda eu vou com a mão" (F1).

O poder do filho mais velho, segundo Áries (1978), ocorre historicamente, desde o século XIII. O protecionismo sobre o filho mais velho tinha por finalidade evitar a perda do patrimônio e a manutenção da linhagem. 
Notamos em muitas famílias que os filhos mais velhos tomam conta dos mais novos em decorrência do surgimento dos aspectos que compõem as relações sociais atualmente, advindas com a necessidade da mulher trabalhar fora do ambiente doméstico para o sustento da família, fazendo com que o papel do irmão mais velho seja de prover cuidado e proteção aos mais novos.

Coerentemente com o nosso referencial teórico, verificamos que a falta de um sistema de apoio, que ofereça respaldo através de orientações familiares adequadas, também favorece os conflitos, como apreendemos a seguir:

\footnotetext{
"O Conselho Tutelar falou pra mim que bater e espancar o filho não pode, então eu não sei como é que a gente faz porque o dia que a polícia trouxe ele aqui, disse que eu tinha que dar um corretivo nele" (F2).
}

A rede de apoio se caracteriza por um conjunto de sistemas e de pessoas significativas que participam do contexto familiar e que é percebido pelo indivíduo. Os recursos da comunidade podem fazer parte desses sistemas de apoio e promover a resiliência familiar através da segurança financeira e assistência social. Em contrapartida a ausência desse tipo de rede pode ser entendida como um fator de risco.

Não podemos deixar de mencionar que, para alguns abrigados, a dificuldade em definir família, seja ela no contexto ideal ou real, esteve presente. 
Podemos explicar tal ocorrência pelo fato de essas crianças e adolescentes viverem em um processo denominado triangulação, ou seja, eles estão constantemente sendo abrigados diversas vezes, fogem para rua tanto de suas casas como do abrigo e essa dinâmica triangular rua/casa/instituição, implica em um desvinculamento dessas crianças e adolescentes com o sentimento de família. Também podemos apreender que a institucionalização concorre para um enfraquecimento desse referencial de origem.

Diante das considerações apontadas nesse subtema, pensar sobre sua realidade, de forma consciente, poderá auxiliar estas crianças e adolescentes a desenvolverem a resiliência familiar e buscarem relações baseadas na estabilidade e reciprocidade.

\section{Subtema 3 - Abrigamento}

O abrigo, de acordo com o ECA, é uma medida de proteção adotada quando todas e quaisquer tentativas de reabilitação da família foram fracassadas, então retira-se a criança da família a fim de protegê-la e conscientizar os pais, para melhor serem trabalhadas fora do contexto da criança, mas sempre com o objetivo de reinseri-la ao seu ambiente de origem. A institucionalização jamais substituirá o ambiente familiar, embora sejam oferecidos pela instituição cuidados básicos de saúde, higiene, alimentação e educação. 
Resultados

Camilla Soccio Martins

Historicamente, a assistência, prestada à criança e ao adolescente em situações de risco, era essencialmente baseada na institucionalização destes, não diferente do que se observa hoje, a contradição de institucionalizar crianças e adolescentes com o objetivo de protegê-los e reinserí-los em seu núcleo familiar de origem, sendo estes, vítima da violência institucional quando abrigados ou então revitimizados quando retornam para suas famílias.

Trazendo o nosso referencial teórico nesta discussão, Brofenbrenner (1996) confirma que o aprendizado infantil se edifica nas múltiplas relações que propiciam uma integração do sujeito em múltiplos universos sociais, levando em conta os modelos que caracterizam os integrantes desse universo. Portanto, a figura do pai ou da mãe constitui um elemento fundamental para a construção da identidade no contexto da família. Assim, a privação do ambiente familiar pode levar a criança a um comprometimento na construção dessa identidade e pode prejudicar a capacidade de encarar a realidade na qual se insere.

Em um dos nossos estudos acerca da reintegração de crianças e adolescentes ao seu lar de origem depois da institucionalização, Martins e Ferriani (2003b) evidenciam que para a maioria das famílias a institucionalização é vista como amparadora de problemas comportamentais, ajudando os pais ao invés de puni-los. Assim, os pais não refletem sobre a violência praticada.

A partir de nossas observações percebemos uma extrema dificuldade dos pais/responsáveis em reconhecer a violência como parte de seu cotidiano e uma 
violação dos direitos da criança e as conseqüências à sua saúde. A seguir, relacionamos as falas da atual pesquisa que contemplam tal contexto:

"Eu não tenho condições, se ele ficasse aqui ia ser pior" (F2).

"Eu tenho muito medo de ter ele de volta" (F3).

Isso também retrata a perceptível acomodação por parte dos pais em se responsabilizar novamente pelo seu filho "rebelde", pois apesar de tudo, na visão dos pais, eles estão sendo muito bem cuidados. De um modo geral, isso revela a violência estrutural e social em que estas famílias se encontram.

Um aspecto marcante é que as crianças e adolescentes apresentavam vínculos fortes com os cuidadores e funcionários do abrigo. De fato, o microssistema familiar é formado pelas pessoas com as quais as crianças e adolescentes abrigados mantêm uma relação próxima e significativa, como no caso os cuidadores. Assim, fica evidente que o núcleo familiar, sob a ótica de crianças e adolescentes, como constatado no subtema 1, é composto por pessoas das quais mantêm relações de afeto e reciprocidade, como no caso os funcionários.

Vale ressaltar que a visão das crianças e adolescentes sobre o abrigo traz a realidade da situação da violência, mas por outro lado conduz a um sentimento 
de não-pertencimento dessa realidade. As falas que seguem confirmam a análise realizada.

"Eu não gosto daqui, porque aqui não é lugar pra mim" (A5).

$$
\begin{aligned}
& \text { "As crianças que estão aqui, os pais espancaram e } \\
& \text { judiaram..."(A4) }
\end{aligned}
$$

Tal percepção dessas crianças e adolescentes, a partir de um sentimento de negação de suas condições, traduz a vulnerabilidade que se encontram caracterizando em um processo de fuga da realidade.

A partir de nossas observações de campo, percebemos a intensa necessidade dessas crianças e adolescentes de se sentirem novamente pertencentes ao microssistema familiar, embora a violência doméstica tenha marcado essas famílias. Elas revelam também a esperança de recuperarem um ambiente familiar que thes proporcione segurança e afeto e admitem a necessidade de voltarem para suas famílias mesmo após serem vitimizados.

“... passou uma luz assim perto de mim e falou que eu vou ser feliz novamente com o meu pai..."(A6) 
"Meu sonho é voltar para a casa e ficar com o meu pai e minha mãe" (A4).

“...Família é uma coisa rara e quem tem não pode deixar perder pra não parar num lugar igual esse" (A1).

A necessidade de preservarem o vínculo nas relações pais-filhos mesmo depois da violência perpetrada pode representar um fator de risco, uma vez que essas relações são sustentadas através da violência, seja qual for sua modalidade de expressão, predispondo à revitimização.

No que se diz respeito ao processo de reinserção na família, podemos notar que os discursos dos pais se dividem. Em duas famílias a volta da criança e do adolescente é encarada como um peso, considerando que o abrigo ainda é o melhor lugar. Fica explícito, no discurso abaixo, mais uma vez, a violência estrutural da qual essas famílias se submetem e são submetidas sendo negado aportes financeiros e sociais para assegurar o desenvolvimento integral dessas crianças e adolescentes.

"É aquela coisa né, a gente às vezes tem saudade dele, mas fica pensando nas coisas erradas que ele faz e tem medo de tirar ele de lá e dar mais trabalho" (F2). 
Resultados

Camilla Soccio Martins

Já em três das famílias, nota-se o desejo de que as crianças e adolescentes voltem pra casa, na tentativa de melhorarem sua situação no papel de famílias. Dentro da perspectiva ecológica, a institucionalização de crianças resulta no prejuízo de seu desenvolvimento psicológico e comportamental, sendo o fator crítico considerado a ausência ou o rompimento de vínculo mãe-criança.

A partir do exposto, presenciamos, em um núcleo familiar, o rompimento definitivo do vínculo com a família, o que poderia ter ocasionado o aparecimento da ausência de perspectiva de vida. Esse rompimento encontra-se relacionado ao tempo de permanência no abrigo, uma vez que para esta adolescente ultrapassou os quatro anos. O comprometimento do vínculo familiar para essas crianças e adolescentes abrigados está quase sempre arraigado ao processo de abrigamento, embora podemos apreender anteriormente que a necessidade de preservação de um "pseudo-vínculo" para essas crianças e adolescentes representam a esperança de saírem da situação em que se encontram, negando suas condições.

Quando perguntamos tanto para as famílias como para os abrigados quais os motivos que levaram ao abrigamento, muitas questões emergiram. Entre essas questões, observamos, tanto entre os pais quanto entre os abrigados, a resistência em mencionar a violência praticada.

Outra questão levantada está relacionada com o desconhecimento da negligência pelos atores sociais e a associação desta com fatores 
socioeconômicos. Como já mencionado, fatores macroestruturais podem desencadear situações associadas à negligência. Podemos complementar este aspecto com as falas a seguir:

“Eu To aqui porque meu pai ainda não arrumou casa pra nós morar" (A4).

"Nós tamo aqui porque meu pai ta com problema nas condições financeiras" (A4).

Uma questão claramente evidenciada e supostamente mascarada é a violência implícita e sutil, mas não menos mutiladora, que ocorre dentro das instituições denominada "violência institucional" que confirma mais uma vez nosso pressuposto da infindável reprodução da violência.

Segundo nossas observações de campo, as relações que se estabelecem entre abrigados e funcionários, embora descritas a partir de vínculos de afeto, muitas vezes, são caracterizados por agressões verbais, desrespeito e até agressões físicas tanto por parte dos abrigados quanto por parte dos educadores do abrigo evidenciando relações de dominação e subordinação.

Constatamos também através dos relatos que coexiste relações de violência e poder entre os próprios abrigados através da imposição de regras 
onde o descumprimento destas geram violência como punição. As falas abaixo relatam essa questão.

"Tem uns muleque aqui que sempre bate em mim e nos meu irmão. Eu não sei porque que sempre os muleque que foge, eles tem que bater no que fugiu" (A6).

Este modelo de funcionamento no microssistema institucional pode ser compreendido como um indicador de risco na medida que reforça a violência através da imposição de poder e dominação.

A partir desses resultados apresentados torna possível reconhecer alguns aspectos da institucionalização e torna viável o investimento em novas estratégias que facilitem a aquisição de novos conhecimentos acerca da violência doméstica.

\subsubsection{Núcleo Temático 2}

\section{Violência}

Consideramos, na análise deste núcleo temático, a forma como se encontra estruturada a violência dentro das famílias. Com base no Referencial Teórico depreendemos dois subtemas: violência doméstica e reprodução da 
violência. O conteúdo desses subtemas agrega os resultados já obtidos e traz a compreensão de fatores desencadeantes da violência doméstica além de comprovar nosso pressuposto acerca da cadeia de reprodução da violência. Entendemos que essa reprodução pode ser evidenciada no dia-a-dia das vítimas e dos agressores da violência doméstica.

\section{Subtema 1 - Violência Doméstica}

As transformações culturais e sociais que hoje incidem sobre a família também determinam a manifestação da violência nesse espaço. A etiologia da violência praticada dentro da família é multicausal, integrando fatores relacionais, contextuais, sociais e psicológicos, elencados aos próprios pais, às crianças, à dinâmica familiar, à comunidade e à sociedade nas quais estão culturalmente inseridos.

$\mathrm{Na}$ busca da literatura, os fatores de risco para desencadear a violência doméstica, segundo Bringioti (1999), são causados por múltiplas influências no contexto ecológico. Segundo a autora, podemos listar dentro do microssistema os fatores de risco como: ciclo ascendente de conflito e agressão, técnicas de disciplinas conflitivas, conflito conjugal e interação pais-filhos desadaptada.

Dentro do exossistema destacamos: desemprego, condições financeiras desfavoráveis, faltas de apoio social, insatisfação no trabalho e perda da autoestima e poder. E por fim podemos citar os fatores de risco dentro do 
macrossistema: crise econômica, aprovação cultural do uso da violência como forma disciplinar e desigualdades sociais.

Nessa perspectiva, os relatos de experiência das famílias estudadas mostram características que pressupõem fatores de risco para o desenvolvimento da violência doméstica. Esses fatores incluem: instabilidade econômica e afetiva, inabilidades de resolver conflitos e buscar soluções efetivas.

Vários autores (AZEVEDO, 2002; GOMES, 2002; MINAYO, 2002; VENDRÚSCOLO, 2004) defendem que podemos incluir como fatores de risco para a instalação da violência dentro da família as desigualdades sociais, a pobreza, o desemprego, o abuso de drogas, a desigualdade de gênero e o histórico anterior de violência.

$\mathrm{Na}$ análise do sistema ecológico, consideram-se os fatores de risco e proteção na avaliação da dinâmica familiar. O mesmo autor ainda salienta que no microssistema familiar podem existir indicadores de risco para a violência, que estariam relacionados a fatores internos e externos a este contexto. Entre os fatores internos destacam-se as formas como são compreendidas e interpretadas as dinâmicas familiares.

Pontuamos que a violência doméstica apareceu quase em todos os discursos, principalmente nos das crianças e adolescentes, quando foi perguntado sobre como era a relação das pessoas dentro da sua família. Para esses atores sociais, a violência faz parte do seu microssistema familiar, pois é vista como uma prática usual neste contexto. 
Dentre as formas de violência relatadas, apareceram a violência punitiva física, a negligência e até a violência sexual. Constatamos a existência de várias formas de violência associadas, sendo rara a prática de apenas um tipo de violência.

Em relação às práticas punitivas violentas expostas, números consideráveis de crianças e adolescentes demonstraram predominar o sentimento de revolta, mágoa, humilhação. De acordo com Bronfenbrenner (1996) as agressões prejudicam a estabilidade do microssistema familiar, pois despertam os sentimentos de humilhação, de menos valia nos seus membros e evidenciam a falta de diálogo.

“..ela fez eu beber água da privada, isso quando eu tinha 7 anos e eu nunca vou esquecer disso!" (A3).

Na perspectiva familiar, a prática punitiva com o uso da força física em crianças e adolescentes revela uma crença nos valores autoritários e no poder dos pais contra os filhos.

Um de nossos estudos acerca da caracterização da violência física realizado na região sudoeste da cidade de Ribeirão Preto constatou que $88 \%$ das vítimas foi agredida mais de três vezes, fato que mostra a prática punitiva, baseada na violência física, como uma atividade ainda aceita socialmente (VIEIRA, D.; MARTINS, C. S.; FERRIANI, M. G. C.; NASCIMENTO, L. C., 2004). 
A negligência, forma mais evidenciada das violências domésticas, esteve presente nos discursos.

"A gente saiu de um lugar podre, a gente era verme, era verme! Comia todo mundo em uma panelinha com a mão, isso quando comia, não tinha calcinha, escova de dente..." (F2)

Ela é representada através da omissão da família e da sociedade no que se refere a cuidar e prover as necessidades físicas e emocionais da criança, entretanto temos um agravante social, ou seja, e se nos depararmos com dificuldades reais devido às condições socioeconômicas dos pais?

Essa questão é de extrema relevância no sentido de que leva ao questionamento da existência da intencionalidade. Encontramos respaldo e preocupação com essa questão até no ECA (BRASIL, 1993) no artigo 23: "A falta ou carência de recursos materiais não constitui motivo suficiente para a perda ou a suspensão do pátrio poder" (p.14).

Referindo-se ainda às formas de violência, o abuso sexual esteve presente em uma das falas dos entrevistados:

“...eu fui estuprada pelo meu padrasto e minha mãe acreditou nele..."(A5) 
Verificamos na referida fala o descrédito, por parte da família, no relato da adolescente quando o abuso é revelado. Estudos de Botelho (2004) apontam que adultas jovens profissionais do sexo viviam intensamente relações conflituosas com a família durante a adolescência e que o abuso sexual era lembrança marcante na vida dessas jovens.

Nos vários momentos da realização da entrevista, puderam ser percebidas as conseqüências das relações violentas vivenciadas. Essas conseqüências incluíam desinteresse, falta de auto-estima e agressividade.

O abandono se constitui em uma das formas mais graves de negligência favorecendo a adoção de atitudes e comportamentos de revolta e agressividade por trás de uma fragilidade. Constatamos o abandono expresso nos discursos.

"Minha mãe me abandonou! Na rodoviária. Isso porque nós fazia bagunça e assim ela não gostava de nós" (A6).

Atentamos para o fato de um acentuado sentimento de culpa sobre a situação, evidenciando o deslocamento da responsabilidade do abandono da mãe para si próprio, ou seja, essa criança acredita que o seu comportamento contribuiu para a prática da violência. 
Tal visão desta criança sobre sua situação mostra a dificuldade de aceitar a situação de abandono da família e impossibilita-a de estabelecer relações baseadas na realidade.

Considerando que a família é o primeiro grupo onde se constroem as identidades individuais, as conseqüências podem ser assoladoras uma vez que favorecem a distorção da realidade e remetem à culpabilização da vítima, desencadeando problemas psicoemocionais.

Através do nosso diário de campo, observamos que muitas crianças e adolescentes possuem comportamentos que denotam sentimentos de culpa.

Das famílias entrevistadas onde a criança ou adolescente vive ou viveu com a mãe e o pai, a maioria desses casais tem, ou já teve problemas conjugais. Deixamos claro que o nosso estudo tem como temática central a violência doméstica contra crianças e adolescentes, mas é impossível desvinculá-la de outras questões como a violência conjugal. Elas estão intrinsecamente relacionadas e quase que dependem uma da outra.

Retomando nosso referencial ecológico, Bronfenbrenner (1996) afirma, através de suas pesquisas, que a capacidade desenvolvimental de uma criança no seu contexto familiar depende da existência e natureza do relacionamento entre os pais. Inversamente, uma indisposição conjugal, culminando em violência, rompe o funcionamento e prejudica o ambiente de socialização da criança.

Podemos considerar também que o fato de a criança e adolescente vivenciarem intensamente esses conflitos conjugais pode desencadear 
comportamentos reprodutores da violência experienciada. Mencionaremos melhor essa questão no próximo subtema que se diz respeito a reprodução dessa violência.

Compreendendo um pouco mais o que os nossos atores sociais relataram sobre as interações familiares produtoras da violência, podemos dizer, de um modo geral, que grande parte das crianças e dos adolescentes entrevistados indicou um desejo de maior convivência ou proximidade física com seu núcleo familiar e a obtenção de uma dinâmica familiar mais estável, permeada de afetuosidade e tolerância.

"...tava faltando algo além do amor e do carinho, tava faltando união e um pouco mais de paciência" (A1). 


\section{Subtema 2- Reprodução da Violência}

A Família, segundo Bronfenbrenner e Morris (1998), é um sistema que busca manter estabilidade e equilíbrio em seus relacionamentos. A estabilidade pode ser ameaçada por mudanças que podem provocar desequilíbrios, como no caso a violência doméstica.

No entanto, as pessoas poderão dispor de mecanismos de proteção que diminuirão a intensidade e severidade do risco pela sua capacidade de resiliência frente a eventos estressores e redes de apoio. Podemos compreender melhor isso no depoimento abaixo:

“... já vi homem morrer na nossa frente de overdose, sabe, então é difícil, eu não sou mais traumatizada porque eu tenho Deus..."( F1)

A resiliência é salientada, no presente estudo, através de irmãos que vivenciaram uma mesma experiência, numa mesma idade e adotam hoje comportamentos distintos frente à situações que desencadeiam a violência.

Por outro lado, crianças e adolescentes que testemunham qualquer tipo de violência tendem a reproduzir, por sua vez, relacionamentos disfuncionais em seu cotidiano. A concepção teórica do ciclo reprodutivo da violência doméstica foi 
uma idéia amplamente difundida nos anos de 1970 e divulgada nos anos de 1980 e 1990.

Ancoramos essas constatações ao nosso pressuposto inicial da reprodução da violência em um ciclo contínuo capaz de permanecer durante toda a vida do indivíduo e, ainda, acrescentamos a implícita exclusão social que acompanha veladamente esse perverso ciclo. A fala apresentada logo abaixo traduz, mesmo que de uma maneira sutil, o que pressupomos anteriormente:

"Quero ver quando eu fizer dezessete anos, para onde eu vou? "(F2)

Esse discurso denuncia claramente o medo da exclusão, por considerar-se abandonado, agredido e por ter sido institucionalizado.

$\mathrm{Na}$ verdade, esse impetuoso ciclo de violência e exclusão começa no núcleo familiar, onde a criança e o adolescente tem seus inalienáveis direitos violados através da violência doméstica em suas múltiplas e cruéis modalidades e isso se segue em sua institucionalização. A institucionalização deveria, teoricamente, funcionar como medida de proteção, mas acaba por evidenciar a violência institucional que mais uma vez vitimiza essa crianças e adolescentes. $\mathrm{Na}$ continuação do ciclo, esses atores sociais voltam para suas casas, onde é revitimizado pela sua família retornando ao início do ciclo, ou então aguardam completar 18 anos e são desabrigados conforme o próprio ECA, que protege esse 
Camilla Soccio Martins

indivíduo até 18 anos sendo logo após lançado na sociedade, desamparadamente, enfrentando a dura cultura de exclusão de pessoas nessa mesma situação.

Seguindo, ainda, na trajetória desse mesmo ciclo, esse indivíduos recaem na questão do próprio rótulo a eles impostos, carregando consigo o preconceito, o desprezo e o descaso tanto do Estado quanto da sociedade e de um modo geral da família. Sendo excluídos e rejeitados pelo mercado formal de trabalho, sua única opção de sobrevivência torna-se viável através da mendicância, dos furtos, do tráfico e consumo de drogas e da prostituição, passando de produto para produtor da violência. Por sua vez, estes, tornan-se uma ameaça à ordem pública e à segurança da sociedade que tentam, através de política públicas, resgatar a cidadania e dignidade mas acabam por serem desarticuladas e excludentes, ignorando as determinações estruturais dessa cadeia e assim fechando o ciclo da violência.

Embora o que refletimos acima é quase uma regra, verificamos que várias falas anteriores revelam a esperança de romper, de alguma forma, a barreira determinada por essa massacrante violência. Citamos como exemplo:

"Quando eu tiver 21 anos e eu tiver trabalhando vou pôr dinheiro pros meus filhos no banco" (A6). 
Ampliando essa análise, podemos dizer que muitas crianças e adolescentes reconhecem a violência como um tipo de aprendizado que será imitado mais tarde. Essas crianças e adolescentes, de acordo com Reppold (2002) "têm a tendência em repetir o comportamento agressivo ou negligente dos pais ou optar por um estilo totalmente oposto, excessivamente permissivo e igualmente prejudicial aos filhos" (p.37).

“Eu apanhei muito, eu apanhava era de cabo de vassoura e panela de pressão" (F5).

"Não pode batê, porque futuramente está ensinando o próprio filho bater ou fazer a mesma coisa com seus filhos quando crescerem" (A3).

“..A única coisa que eu sou, assim, é muito brigão, meu pai e minha mãe brigavam muito, ... eu gosto de brigar, mas eu tento controlar..." (A1)

“... Eu era terrível mesmo e quanto mais eu apanhava, mais eu brigava..." (A1) 
Podemos chamar isso de multigeracionalidade, ou seja, muitas crianças acabam por ser negligenciadas por sua mães, ignoradas por sua existência e fisicamente agredidas pelos pais, abusadas sexualmente por padrastos mostrando um círculo perverso que produzem e são produtos da violência.

Esses achados conferem com nosso referencial teórico ecológico, que comprova que o ativo envolvimento ou a mera exposição àquilo que as pessoas realizam, no caso a violência, geralmente inspira o observador ou expositor a realizar atividades semelhantes sozinho e isso se aplica especialmente às crianças.

Vale ressaltar, um aspecto interessante notado nas entrevistas que foi a consciência dessas crianças acerca de seus direitos. Tal fato pode ser compreendido com o advento do ECA e a sua divulgação na mídia tornando seus preceitos acessíveis à população, no entanto, impassíveis de serem cumpridos. Verificamos tal situação nitidamente nesta fala:

“..se você estiver espancando seus filhos, você tem que parar e pensar porque vai ser pior pra você. Pensa pra depois fazer" (A6).

"As próprias crianças tem direito à vida, à liberdade e a educação e os pais não devem proibi-los, todos os direitos são das crianças" (A6). 
A desestruturação dessas famílias no nível de suas relações interpessoais gera condições para a instalação de situações de violência. Entendemos assim que as condições desse meio no qual essas crianças e adolescentes estiveram inseridos contribuíram para a adoção de comportamentos violentos.

A violência não se reduz a práticas objetivas, temos que ela também revela-se pelas representações que seus atores fazem dela. Assim, fica claro que essas crianças e adolescentes banalizam a violência vivida tornando-a suscetível de ser negada. Concordamos com Minayo e Souza (1999) que compreendem a violência como: "um comportamento aprendido e culturalizado que passa a fazer parte dos padrões intrapsíquicos, dando a falsa impressão de ser parte da natureza biológica dos seres humanos" (p.11). 


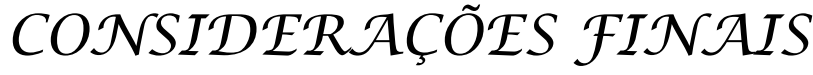




\section{CONSIDERAÇÕES FINAIS}

etomando a trajetória deste trabalho e voltando ao nosso objetivo geral que foi conhecer e analisar a compreensão de família para pais e filhos envolvidos no episódio da Violência Doméstica contra crianças e adolescentes institucionalizados no Centro de Atendimento à Criança e ao Adolescente Vitimizados, constatamos duas temáticas: o contexto familiar e a violência.

Em relação à primeira temática, apreendeu-se que a visão dos pais sobre a composição familiar diferencia das visões das crianças e adolescentes abrigados, uma vez que a ótica dos pais favorece a compreensão da família como nuclear e as crianças apontam que o vínculo de amor e afeição é mais significativos que laços consangüíneos.

Deste modo, torna-se evidente que, para essas crianças e adolescentes, a maneira de enxergar a família pode representar um fator de proteção, pois isso permite ampliar a rede de apoio pertencente ao microssistema familiar, que vai além do grau de parentesco.

Ainda no mesmo núcleo temático, um ponto que merece destaque referese à idealização dos pais quando estes estão ausentes. A institucionalização, de alguma forma, contribui para preservar uma imagem de pais que só existe na esfera do ideal, impedindo que essas crianças e adolescentes enfrentem a realidade em que vivem. 
A dificuldade de definir família, seja ela no contexto ideal ou real, foi um fator presente, considerando que a institucionalização pode enfraquecer o referencial de família.

Nesse sentido torna-se uma tarefa difícil a intervenção junto às famílias, uma vez que a violência é subjugada pela mesma. De qualquer forma, é importante considerar que a partir do conhecimento da dinâmica familiar e da forma como a violência é experienciada pelas suas vítimas e agressores é que podemos pensar em uma estratégia de intervenção capaz de romper o ciclo das relações familiares violentas.

Em relação à segunda temática, procurou-se contextualizar a violência em seu sentido mais amplo. Podemos dizer que essas crianças e adolescentes demonstraram dificuldades em encarar seu microssistema familiar de forma realística. Essa visão favorece o sentimento de culpa sobre a situação de violência e acaba por deslocar a responsabilidade da violência doméstica para essas crianças e adolescentes.

Evidenciamos também que o fato de a criança e do adolescente testemunharem ou vivenciarem a violência doméstica, tenderá a reproduzir, por sua vez, relacionamentos violentos, perpetuando, assim, a cadeia de transmissão da violência doméstica. Essa constatação vem ao encontro do nosso pressuposto.

Assim, o fato de a violência doméstica estar presente, aumentariam muito as chances de uma criança ou adolescente tornarem-se futuros agressores em potencial. Valorizar os fatores de proteção que com certeza poderão amenizar os 
riscos das conseqüências da violência é sem dúvida o ponto-chave para intervir nessa problemática.

Acreditamos que focalizar a família, tendo como eixo norteador a Teoria dos Sistemas Ecológicos proposta por Bronfenbrenner, trará contribuições não só para a compreensão dos fatores que permeiam a etiologia da violência e suas relações manifestadas dentro da família como também para o incentivo de pesquisas no âmbito da família para gerar e implementar alternativas a médio e longo prazos.

A tolerância às diferenças representa o grande vínculo que faz da família a estrutura social e emocional dos seus membros. Todos os esforços na direção do espaço do entendimento acionam efetivas formas de lidar com os conflitos familiares em todos os níveis. Nesse sentido, pensar família numa forma plural significa uma construção individual baseada na tolerância com as diferenças.

É preciso buscar, cada vez mais, desenvolver pesquisas e programas com visões mais ampliadas, para abarcar a vítima, o agressor e o restante do grupo familiar.

O despreparo e a falta de qualificação por parte dos profissionais de saúde trazem em si a falta de possibilidade de agir ecologicamente no meio familiar, entendendo o desenvolvimento humano e suas múltiplas facetas mediante uma visão de saúde.

Os resultados apontados nesta pesquisa podem se tornar ferramentas fundamentais para incentivar a implantação de programas de intervenção e 
prevenção da violência doméstica no contexto ecológico onde ela se desenvolve. A conscientização das famílias sobre os seus comportamentos e relacionamentos desencadeantes da violência pode funcionar como promotores da resiliência.

Certamente ainda existem muitas limitações, nem todos os problemas poderão ser resolvidos e muitos fatores independem das ações dos profissionais de enfermagem.

Devemos considerar a importância de uma articulação de ações conjuntas no campo da assistência social, sistema judiciário e conselhos tutelares no sentido de efetivar os casos notificados de violência doméstica.

A estratégia governamental, implementada no Brasil, denominada Programa de Saúde da Família abre uma possibilidade de extensão da prática da enfermagem na identificação e prevenção da violência doméstica, embora essa prática requer um embasamento em um conhecimento específico, construído através de pesquisas que possam subsidiar a prática.

É preciso conhecer a rede de apoio e as diferentes facetas da mesma história para compreender e resgatar os fragmentos que constituem a realidade da violência doméstica. É fundamental, portanto, que se busquem respostas para este recorte, ou eventos a eles relacionados, partindo de realidades existentes. As ações devem se direcionar no sentido de transformações das estruturas sociais que potencializam ou causam a violência, levando em conta as normas e valores que legitimem a violência.

Além disso julgamos imprescindível a preparação, sendo capaz de construir conhecimentos, divulgando-os e criando estratégias de trabalho 
adequados a todos os membros da equipe multiprofissional. Devemos nos lançar um pouco mais além e incluir a interdisciplinaridade e intersetoridade na promoção, prevenção e encaminhamento adequado ao caso no âmbito da justiça, da segurança pública, dos movimentos sociais, da saúde pública e até da educação.

A visão predominante da responsabilização da família sobre as situações de violência vem perdendo força. Atualmente um olhar ampliado sobre a questão busca enxergar não só a desestruturação familiar mas sim o seu dinamismo, identificando pontos de vulnerabiliadade, correlacionando fatores culturais, psicológicos, relacionais e socioeconômicos.

Novos marcos sociais e legais relativos à violência contra a criança ainda não estão totalmente integrados na prática dos profissionais de saúde, criandoIhes dilemas que via de regra não estão preparados a enfrentar. Um desses problemas é a forma de lidar com os direitos conquistados pela criança recentemente.

A abordagem ecológica do nosso estudo inspira uma reorientação no avanço das pesquisas sociais e na implementação de políticas públicas. Bronfenbrenner (1996) enfatiza: "A política pública é uma parte do macrossistema determinando as propriedades específicas dos exo-, meso- e microssistemas que ocorrem no nível da vida cotidiana e governam o curso do comportamento e desenvolvimento humano" (p.9).

Acreditamos que cada uma dessas perspectivas assinaladas, dentro da estrutura mais ampla do sistema de significados, reflete a realidade pelas quais 
Camilla Soccio Martins

passam as famílias. Eles próprios são estruturados pelas restrições e desigualdades mais amplas impostas pelo macrossistema. Refletir os limites e a amplitude desses resultados é de fundamental importância para a prevenção e redução da violência doméstica contra crianças e adolescentes. 
REFER $\hat{\mathcal{E}} \mathcal{N} C I \mathcal{A} S$ 
6. REFERÊNCIAS

ALMEIDA, E. C. Violência doméstica: um desafio para a formação do pediatra. 1998. 111 f. Dissertação (Mestrado) - Universidade do Estado do Rio de Janeiro, Instituto de Medicina Social, Rio de Janeiro, 1998.

AOKI, L. P. S.; TARDELI, R. Aspectos jurídicos da concepção de família na sociedade brasileira. Rev. Bras. Crescimento Desenvolv. Humano, v. 4, n. 1, p. 5-14, jan.-jun. 1994.

ARIÈS, P. História social da criança e da família. Rio de Janeiro: Zahar, 1978.

AYRES, J. C. M. O jovem que buscamos e o encontro que queremos ser. In: TOZZI, D. a Papel da educação na ação preventiva abuso de drogas e as DSTI AIDS - São Paulo: FDE - Fundação para o desenvolvimento da Educação, 1996. p. $25-42$.

ASSIS, S. G. Crescendo em meio à violência. In: WESTPHAL, M. F. (Org.). Violência e criança. São Paulo: EDUSP, 2002. p. 115-124.

ASSOCIAÇÃO BRASILEIRA MULTIPROFISSIONAL DE PROTEÇÃO À INFANCIA E ADOLESCENCIA (ABRAPIA). Maus-tratos contra crianças 
adolescentes: proteção e prevenção: guia de orientação para professores. Petrópolis: Autores \& Agentes Associados, 1992. 32 p.

AZEVEDO, M. A.; GUERRA, V. N. A. Pele de asno não é só história: um estudo sobre a vitimização sexual de crianças e adolescente em família. São Paulo: Roca, 1988.

AZEVEDO, M. A.; GUERRA, V. N. A. Crianças vitimizadas: a síndrome do pequeno poder. São Paulo: Iglu, 1989.

AZEVEDO, M. A.; GUERRA, V. N. A. Infância e violência fatal em família. São Paulo: Roca, 1998. 248 p.

AZEVEDO, M. A. Contribuições brasileiras à prevenção da violência doméstica contra crianças e adolescentes. In: WESTPHAL, M. F. (Org.). Violência e criança. São Paulo: EDUSP, 2002. p. 115-124.

BARDIN, L. Análise de conteúdo. Tradução de Luis Antonio Reto e Augusto Pinheiro. Lisboa: Edições 70, 1979.

BRASIL. Código Civil Brasileiro. Lei 1046 de 10 de janeiro de 2002. São Paulo: Saraiva, 2003. 
BRASIL. Estatuto da Criança e do Adolescente. Lei nº 8069 de 13 de julho de 1988. São Paulo, 1988.

BRASIL. Lei n. 8.069 de 13 de julho de 1990. Dispõe sobre o Estatuto da Criança e do Adolescente e dá outras providências. Brasília: Ministério do BemEstar-Social; Centro Brasileiro para a Infância e Adolescência, 1993.

BRASIL. Ministério da Saúde. Saúde e desenvolvimento da juventude brasileira. Construindo uma agenda nacional. Brasília: Ministério da Saúde, 1999. 21 p.

BRASIL. Ministério da Justiça. Plano nacional de enfrentamento da violência sexual infanto-juvenil. Brasília: Ministério da Justiça; Secretaria de Estado dos Direitos Humanos/Departamento da Criança e do Adolescente, 2001b

BRASIL. Ministério da Saúde. Secretaria de Assistência à Saúde. Notificação de maus-tratos contra crianças e adolescentes pelos profissionais de saúde: um passo a mais na cidadania em saúde. Brasília: Ministério da Saúde, 2002.

BRASIL. Ministério da Educação/INEP. Censo escolar. Disponível em: <http://www.inep.gov.br/impress/noticias/censo/escolar/ Acessado em: 20 de fev. de 2004. 
BRAVO, M. Incesto y violación. Chile: Academia, 1994.

BELSKY, J. Etiology of child maltreatment: a developmental-ecological analysis. Psychol. Bull., v. 114, p. 413-434, 1993.

BOTELHO, S. M. N.; FERRIANI, M. G. C. Prostituição na adolescência: interfaces com a instituição familiar. Rev. Assoc. Bras. Enfermagem , v. 57, n. 2, p. 198202, mar.-abr. 2004.

BOULDING, E. Las mujeres y la violencia social. In: La violencia y sus causas. Paris: UNESCO, 1981.

BIASOLI, Z. M. M.; FISCHMANN, R. (Org.). Crianças e adolescentes: construindo uma cultura de tolerância. São Paulo: Edusp, 2001. 220 p. (Série Ciências, Cientistas e Tolerância).

BILAC, E. D. Famílias de trabalhadores estratégias de sobrevivência. São Paulo, Símbolo, 1978.

BRINGIOTTI, M. I. El impacto de los malos tratos en ell desarollo psicosocial. Em: BRINGIOTTI, M. I. Maltrato infantil: factores de riesgo para el maltrato físico en la problación infantil que concurre a las escuelas dependientes del Gobierno de la Ciudad de Buenos Aires. Madrid: Niño y Dávila, 1999. Cap. 5, p. 67-70. 
BRONFENBRENNER, U. A ecologia do desenvolvimento humano: experimentos naturais e planejados. Porto Alegre: Artes Médicas, 1996.

BRONFENBRENNER, U.; MORRIS, P. (1998). The ecology of developmental processes. Em W. Damon (Org), Handbook of child psychology v.1, p.9931027. New York.

CANEVACCI, M. Dialética da família. São Paulo: Brasiliense, 1984.

COSTA, J. F. Ordem médica e norma familiar. Rio de Janeiro: Graal, 1983.

DAHER, M. P. Projeto criança. Departamento de Psicologia da Universidade Federal do Paraná, 2003. Disponível em: $<$ http//www.Brasil.terravista.pt/Ipanema/2172/substituta.htm> Acesso em: 10 de jul. de 2003.

De ANTONI, C.; SIMÕES, A. M. R.; MARTINS, C. M.; COSTA, F. R.; FERRONATO, M. E. B.; MAURENTE, V. S.; KOLLER, S. H. A família na visão de adolescentes maltratadas. In: CONGRESSO BRASILEIRO DE PSICOLOGIA DO DESENVOLVIMENTO, 3,. Desenvolvimento e Práticas Sociais, Anais. Gramado RS., 2000. p. 132. 
De ANTONI, C.; KOLLER, S. H. O psicológico ecológico no contexto institucional: uma experiência com meninas vítimas de violência. Psicol. Ci. Prof., v. 21, n. 1, p. 14-29, 2001.

DEL PRIORE, M. (Org.). História da criança no Brasil. 2 ed. São Paulo: Contexto, 1992.

DESLANDES, S. F. Prevenir a violência: um desafio para os profissionais de saúde. Rio de Janeiro: FIOCRUZ/ENSP/CLAVES; Jorge Careli, 1994. 39 p.

DIAS, M. L. Vivendo em família: relações de afeto e conflito. 7. ed. São Paulo: Moderna, 1992. p. 69.

DINIZ, M. H. Código civil brasileiro: direito de família. São Paulo: Saraiva, 2002. v. 5.

ENGELS, F. A origem da família da propriedade privada e do Estado. 14. ed. Rio de Janeiro: Bertrand Brasil, 1997.

FALEIROS, V. de P.; FALEIROS, E. T. S. (Coord.). Circuitos e curtos-circuitos: atendimento, defesa e responsabilização sexual contra crianças e adolescentes. São Paulo: Veras, 2001. 
FERREIRA, A. L.; SCHRAMM, F.R. Implicações éticas da violência doméstica contra a criança para profissionais de saúde. Rev. Saúde Pública, v. 34, n. 6, 2000.

FERRIANI, M. G. C. A criança e o adolescente alvos de atos violentos ou vítimas potenciais da violência - Projeto Temático/FAPESP. Ribeirão Preto: EERP/USP, 2000.

FONSECA, M. C. A. D. A representação social da família pelo dependente de drogas. 1997.104 f. Dissertação (Mestrado) - Faculdade de Saúde Pública da Universidade de São Paulo, São Paulo, 1997.

GOMES, R. A análise de dados em pesquisa qualitativa. In: MINAYO, M. C. S. (Org.). Pesquisa social: teoria, método e criatividade. Petrópolis: Vozes, 2001.

GOMES, R. et al. A abordagem dos maus-tratos contra a criança e o adolescente em uma unidade pública de saúde. Ci. Saúde Coletiva, v. 7, n. 2, 2002.

GUERRA, V. N. A.; SANTORO, M.; AZEVEDO, M. A. Violência doméstica contra crianças e adolescentes e políticas de atendimento: do silêncio ao compromisso. Rev. Bras. Crescimento e Desenv. Humano, v. 2, n. 1, p. 71, 1992. 
HAIM GRÜNSPUN. Autoridades dos pais e educação da liberdade. 3. ed. São Paulo: Almed, 1985.

IOSSI, M. A. Um caminhar necessário: a participação dos profissionais da saúde na assistência às crianças vítimas de violência doméstica. Ribeirão Preto, 2004. 126 f. Tese (Doutorado) - Escola de Enfermagem de Ribeirão Preto, Universidade de São Paulo, Ribeirão Preto, 2004.

MARQUES, M. Violência doméstica contra crianças e adolescentes. Rio de Janeiro: Vozes, 1994.

MARTINS, C. S.; FERRIANI, M. G. C. Caracterização dos agressores e vítimas de violência sexual intrafamiliar: um estudo de caso. Rev. Bras. Sexualidade Humana, v. 14, n. 1, p. 129-139, 2003a.

MARTINS, C. S.; FERRIANI, M. G. C. Reintegração da criança e do adolescente vitimizados na percepção dos pais. Rev. Assoc. Bras. Enfermagem-REBEN, v. 56, n. 6, p. 651-654, 2003b.

MERISSE, A. Origem das instituições de atendimento à criança pequena: o caso das creches. In: JUSTO, J. S.; ROCHA, L. C.; VASCONCELOS, M. S. (Org.). Lugares da infância: reflexões sobre a história da criança na fábrica, creche e orfanato. São Paulo: Arte e Ciência, 1997. 
MINAYO, M. C. S. A violência social sb a pesrpectiva da saúde pública. Cadernos de Saúde Pública, Rio de Janeiro, v.10, p.7-18, 1994.

MINAYO, M. C. S. O desafio do conhecimento: pesquisa qualitativa em saúde. 4ª ed. São Paulo: Rio de Janeiro: Abrasco, 1996.

MINAYO, M. C. S. O significado social e para a saúde da violência contra crianças e adolescentes. In: WESTPHAL, M. F. (Org.). Violência e criança. São Paulo: EDUSP, 2002. p. 95-114.

MINAYO, M. C. S.; SANCHES, O. Quantitativo-qualitativo: oposição ou complementariedade? Cad. Saúde Pública, v. 9, n. 3, p. 239, 1993.

MINAYO, M. C. S.; SOUZA, E. R. É possível prevenir a violência? Reflexões a partir do campo da saúde pública. Ciência \& Saúde Coletiva, v. 4, n. 1, 1999.

MONTEIRO, L. P. Do objeto da violência: a infância. In: SOUSA, S. M. G. (Org.). Infância, adolescência e família. Goiânia: Cânone Editorial, 2001, p. 133-154.

ORGANIZAÇÃO MUNDIAL DA SAÚDE - OMS. Relatório mundial sobre violência e saúde. Genebra: OMS, 2002. 
ORGANIZAÇÃO PAN-AMERICANA DA SAÚDE - OPS. Epidemiologia das desigualdades em saúde no Brasil. Brasília: OPAS, 2002.

PIMENTEL, S. Revista Serviço Social e Sociedade, ano XXIII, n.71, setembro, 2002.

REIS, J. N. Violência sexual contra mulheres: análise de dados relacionados ao estupro e atentado violento ao pudor legalmente registrados em Ribeirão Preto SP. 2001. 132 f. Dissertação (Mestrado) - Faculdade de Medicina de Ribeirão Preto da Universidade de São Paulo, Ribeirão Preto, 2001.

REPPOLD, C.T. et al. Prevenção de problemas de comportamento e o desenvolvimento de competências psicossociais em crianças e adolescentes: uma análise das práticas educativas e dos estilos parentais. In: HUTZ. C. S. (Org.). Situações de risco e vulnerabilidade na Infância e na adolescência: aspectos teóricos e estratégias de intervenção. São Paulo: Casa do Psicólogo, 2002. p.11-51.

RIBEIRÃO PRETO. Prefeitura Municipal. Secretaria Municipal da Cidadania e Desenvolvimento Social. Rede crescer. Ribeirão Preto, 2002. 
RIBEIRO, M. A. Prostituição de adolescentes: uma imagem construída na adversidade da sociedade. 2003. 142 f. Dissertação (Mestrado) - Escola de Enfermagem de Ribeirão Preto, Universidade de São Paulo, Ribeirão Preto, 2003.

RIBEIRO, M. A. Violência sexual intrafamiliar contra crianças e adolescentes: estudo realizado no Centro de Referência da Criança e do Adolescente e nos Conselhos Tutelares no município de Ribeirão Preto-SP. 2002. 154 f. Dissertação (Mestrado) - Escola de Enfermagem de Ribeirão Preto, Universidade de São Paulo, Ribeirão Preto, 2002.

ROQUE, E. M. S. T. A violência na família contra crianças e adolescentes e a percepção dos operadores do direito, na comarca de Jardinópolis-SP. 2001. 226 f. Dissertação (Mestrado) - Escola de Enfermagem de Ribeirão Preto da Universidade de São Paulo, Ribeirão Preto, 2001.

ROMANELLI, G. Autoridade e poder na família. In: CARVALHO, M. do C. B. de (Org.). A família contemporânea em debate. 2. ed. São Paulo: EDUC/Cortez, 1995.

SAITO, M. I. Adolescência, cultura, vulnerabilidade e risco. A prevenção em questão. In: SAITO, M. I.; SILVA, L. E. V. Adolescência: prevenção e risco. São Paulo: Atheneu, 2001. p. 33-38. 
SALOMON, Z. Situação da criança e do adolescente em Israel: crescendo em ambientes violentos - vulnerabilidade e resiliência. In: WESTPHAL, M. F. (Org.). Violência e criança. São Paulo: EDUSP, 2002. p. 73-91.

SANTOS, M. C. C. L. Raízes da violência na criança e danos psíquicos. In: WESTPHAL, M. F. (Org.). Violência e criança. São Paulo: EDUSP, 2002. p. 189-204.

SARTI, C. A. A continuidade entre casa e rua no mundo da criança pobre. Rev. Bras. Crescimento e Desenvol. Humano, v. 5, n. 1/2, p. 39-47, jan.-dez. 1995.

Seade. Departamento de Desenvolvimento Econômico. Disponível em http:// www.seade.com.br. Acesso em: 15 de julho de 2004.

SOCIEDADE BRASILEIRA DE PEDIATRIA. Guia de atuação frente a maustratos na infância e na adolescência: orientações para pediatras e demais profissionais da saúde. Rio de Janeiro: SBP/CLAVES/FIOCRUZ/MJ, s/d. 40 p.

SZYMANSKI, H. Teorias e "teorias" de famílias. In: CARVALHO, M. C. B. (Org.). A família contemporâneo em debate. São Paulo: EDUC, 1997. p. 23-27.

SZYMANSKI, H. A relação família/escola: desafios e perspectivas. Brasília: Plano Editora, 2001. 
TAYLOR, C. M. Fundamentos de enfermagem psiquiátrica de Mereness. Tradução Dayse Batista. 13. ed. Porto Alegre: Artes Médicas, 1992. Cap. 5, p. $397-411$.

TRIVIÑOS, A. N.S. Introdução à pesquisa em ciências sociais: a pesquisa qualitativa em educação. São Paulo: Atlas, 1995.

UNICEF. Família brasileira: a base de tudo. São Paulo: Cortez, 1994.

WOOD, G. L.; HABER, J. Pesquisa em Enfermagem: métodos, avaliação crítica e utilização. 4 ed. Rio de Janeiro: Guanabara Koogan, 2001.

WRIGHT, L. M.; LEAHEY, M. Enfermeiras e famílias: um guia para avaliação e intervenção na família. 3 ed. São Paulo: Roca, 2002.

VENDRÚSCOLO, T. S. et al. As políticas sociais e a violência: uma proposta de Ribeirão Preto. Rev. Latino-am. Enfermagem, v. 12, n. 3, 2004.

VENDRÚSCULO, T. S. Políticas e prioridades políticas: a experiência de Ribeirão Preto no atendimento à criança e ao adolescente, vítimas de violência doméstica. 2004. 291 f. Tese (Doutorado) - Escola de Enfermagem de Ribeirão Preto da Universidade de São Paulo, Ribeirão Preto, 2004. 
VIEIRA, D; MARTINS, C. S.; FERRIANI, M. G. C.; NASCIMENTO, L. C. Caracterização da violência física contra crianças e adolescentes. Rev. Enfermagem UERJ, v. 12, n. 3, p. 306-311, set./dez. 2004. 


\section{APÊNDICE A}

Perguntas norteadoras da entrevista semi-estruturada para a família

1. Nome:

2. Idade:

3. Parentesco do agressor:

4. Idade do agressor:

5. Escolaridade do agressor:

6. Tipo de violência perpetrada:

7. Número de membros da família/ ou que moram juntos:

8. Desempregados:

9. Alcoólatras

10. Drogadiços:

11. Número de vítimas:

12. Idade da vítima(s):

13. Tempo de institucionalização:

14. Quantas vezes foi institucionalizado:

15. Situação do processo da justiça:

16. Denúncia realizada por:

17. Participação do grupo de pais:

18. Irmãos já foram vítimas? Quantas vezes? 
Perguntas norteadoras da entrevista semi-estruturada para os pais

1.Para você o que a palavra família quer dizer? Por quê?

2.Como você gostaria que sua família fosse? Por quê?

3. Como é a relação entre vocês em casa?

4. O que levou a acontecer a violência?

3.Como os pais deveriam ser com os filhos?

6.O que você acha do que aconteceu na sua família?

7. Qual a conseqüência que isso trouxe para sua família?

8.Você acha que acontece isso em todas as famílias? Por quê?

9.0 que seus filhos pensam de você?

10.Quando uma criança faz algo de errado, o que os pais devem fazer? 
Perguntas norteadoras da entrevista semi-estruturada para os filhos

1.Para você o que a palavra família quer dizer? Por quê?

2.Como você gostaria que sua família fosse? Por quê?

3. Como é a relação entre vocês em casa?

4. O que levou a acontecer a violência?

3.Como os filhos deveriam ser com os filhos?

6.0 que você acha do que aconteceu com você?

7. Qual a consequência que isso trouxe para sua família?

8.Você acha que acontece isso em todas as famílias? Porquê?

9. O que seus pais pensam de você?

10.Quando uma criança faz algo de errado, o que os pais devem fazer? 


\title{
RIBEIRÃO PRETO, JULHO DE 2004
}

\author{
TERMO DE CONSENTIMENTO LIVRE E ESCLARECIDO DE PESQUISA EM \\ SERES HUMANOS.
}

Prezado(a) Senhor(a)

Estamos realizando uma pesquisa sobre a compreensão de família . Os dados se destinarão à elaboração de dissertação de Mestrado a ser apresentada à Escola de Enfermagem de Ribeirão Preto/USP (EERP/USP).

Será garantido o sigilo e o anonimato do entrevistado, o que não lhe causará nenhum dano ou exposição.

Para tanto, solicitamos a vossa colaboração em participar de uma entrevista que será registrada pelo pesquisador no momento da emissão das respostas.

Você poderá fazer todas as perguntar que julgar necessário para o esclarecimento de suas dúvidas, tendo a liberdade de retirar seu consentimento e deixar de participar da pesquisa assim que desejar, sem penalização alguma.

Atenciosamente,

$\overline{\text { Camilla Soccio Martins }}$

Contato: Rua Martinico Prado, 677 apto 91. Fone: 16- 39314914

\section{AUTORIZAÇÃO}

RG

$\mathrm{Eu}$,

RG , declaro que concordo que

participe voluntariamente da pesquisa "A compreensão de família para os membros do núcleo familiar envolvidos na violência doméstica contra crianças e adolescentes" que tem por objetivo identificar, na visão dos membros do núcleo familiar, o significado de família.

Fui devidamente informado que a entrevista será gravada e não terei meu nome revelado e que posso recusar-me a participar da pesquisa em qualquer momento, que estas informações serão sigilosas e que não terei prejuízos físicos e financeiros. 


\section{APÊNDICE C}

\section{FAMÍLIA 1}

Abrigado: E, 14 anos, sexo masculino

Tempo de permanência no abrigo: um ano e cinco meses.

Tipo de violência perpetrada pelos pais: Negligência e violência física.

Residia com mais cinco irmãos e com o padrasto, sendo 2 filhos deste.

A mãe e padrasto eram usuário de drogas e álcool (pai faleu em decorrência de ter contraído HIV). Suas relações eram baseadas na violência havendo constante carência de alimentos e vestimentas.

Mãe também faleceu em decorrência de ter contraído HIV quando o abrigado tinha quatro anos de idade. Todos os filhos foram morar com a vizinha.

Atualmente a composição familiar:

Ana Cláudia (irmã) 21 anos

E. (irmã) 22 anos, engravidou aos 13 anos e saiu de casa

J. (irmã) 19 anos, vive em um convento no Rio de Janeiro

W. (irmão) 16 anos

M. (irmã) 10 anos.

O abrigado residia, antes de entrar na instituição, com a vizinha e seus outros irmãos.

Foi abrigado em 13/10/2003 encaminhado pelo Conselho Tutelar, por ter sido encontrado na rua.

Atualmente, este apresenta problemas de conduta dentro do abrigo. Foram registrados dois boletins de ocorrência na delegacia por motivos de agressão deste com os funcionários e outros abrigados. Ele é acompanhado semanalmente por psicóloga e constantemente foge do abrigo com outros abrigados e vão para a rua.

$\mathrm{Na}$ escola é muito agressivo com os outros alunos e por esta razão foi transfererido 2 vezes para outras escolas.

Segundo a psicóloga do abrigo, este apresenta inabilidade emocional para interação interpessoal buscando isolamento.

A vizinha com que residia tem 60 anos, tem problemas de saúde e se nega ter condições para cuidar dele e suas duas irmãs maiores não querem assumir sua guarda pois alegam ter medo de constantes agressões.

Motivo do abrigamento: abandono por parte da vizinha, da qual tinha sua guarda de fato e não de direito. (ele fugiu de casa).

A irmã mais velha comparecia às reuniões de pais do abrigo, mas só por algum tempo, depois ela desistiu. 
FAMÍLIA 2

Abrigado: J., 11 anos, sexo masculino.

Tempo de abrigamento: 10 meses.

Tipo de violência perpetrada pelos pais: Violência física.

Mãe separada do pai e vive com outro marido que possui com este 2 filhos.

Atualmente a composição familiar:

Mãe

Padrasto que trabalha em uma madeireira

Irmã-3 anos (filha do padrasto com a mãe)

Irmão-2 anos (filho do padrasto com a mãe)

Este foi abrigado em 5 de maio de 2004 e foi desabrigado 2 dias depois, sendo abrigado novamente em 17 de maio do mesmo ano.

Segundo o mesmo, a mãe que obrigava-o pegar garrafas pet na rua e vender. Apresenta agressividade excessiva na escola.

A mãe foi espontaneamente no abrigo dizer que não o queria porque ele dava muito trabalho e 2 meses depois ele foi abrigado porque a escola denunciou maus-tratos e abandono.

Atualmente o abrigado não recebe visitas do pai nem da mãe. A Mãe diz que não quer ficar com ele, que agora é a vez do pai assumí-lo, e por sua vez o pai não quer. 
FAMÍLIA 3

Abrigado: L., 14 anos, sexo masculino

Tempo de abrigamento: 2 meses

Violência perpetrada: Violência Física.

Pai faleceu por ter contraído HIV antes dele nascer e mãe também faleceu do mesmo motivo quando o abrigado possuía cinco anos de idade, até então morava com a mãe na casa da tia (irmã da Mãe), que ficou com a guarda deste quando a mãe morreu.

Atualmente a composição familiar:

Tia ( irmã da Mãe)

Irmã-15 anos

Este foi abrigado pela primeira vez em agosto de 2002 e ficou 1 ano e dois meses no abrigo por uma denúncia feita pela escola de abuso de drogas pela tia, sendo desabrigado em outubro de 2003 e novamente abrigado.

Segundo a escola, ele é muito agressivo com os colegas e fica exibindo seu genital para as meninas. Pais da escola acionaram a secretaria da educação.

Ele fugia do abrigo e dormia na rua convivendo com andarilhos, foi ao psiquiatra e foi diagnosticado: Distúrbio de Comportamento tipo agressivo. De acordo com o parecer da psicóloga do abrigo, ele apresenta e vivencia um intenso sentimento de rejeição e necessidade de auto-punição.

Quando estava em casa dormia com faca e objetos cortantes debaixo da cama e sempre ameaça a tia de morte. 
FAMÍLIA 4

Abrigados: R, 16 anos, sexo masculino.

L, 13 anos, sexo masculino.

Tempo de abrigamento: 3 anos.

Violência perpetrada: Negligência.

Os pais possuem comprometimento psicológico sendo que a mãe faz acompanhamento psiquiátrico.

Atualmente a composição familiar:

Mãe

Pai

L, 15 anos (já foi abrigada)

A família tem dificuldades econômicas sendo que o pai não tem moradia fixa e a mãe não tem condição psicológicas de cuidar dos filhos.

Em março de 2002, o tio paterno fez a denúncia de que o pai abandonou a casa e a mãe é deficiente mental e não cuida das crianças, ficando estas sem água e comida.

Em 11 de março de 2002, os três filhos foram abrigados. Em entrevista do conselho tutelar com os abrigados, descobriu-se que o pai às vezes perde 0 controle e bate nos seus filhos com instrumentos e que teria ocorrido um provável abuso sexual do pai contra a filha biológica, fato que todas as crianças confessaram mas não foi confirmado.

Enquanto abrigados, os adolescentes não apresentavam vínculo afetivo com seus genitores e recusam a recebê-los, principalmente a filha.

Pais visitam as crianças esporadicamente e todas as tentativas de reinserção na família foram infrutíferas.

Em novembro de 2003 a tia paterna assumiu a guarda da irmã, mas os outros dois irmão continuaram abrigados. Luciana enquanto abrigada não respeitava as regras e nem funcionários, agredia as crianças menores, fato que foi obrigada a prestar serviços à comunidade.

Depois que a tia conseguiu a guarda de Luciana, queria devolvê-la, porém permanece até hoje com a tia.

Nota-se, segundo as assistentes sociais do abrigo, uma certa acomodação dos familiares e até mesmo dos genitores com relação ao abrigo dos adolescentes, visto que os pais chegam a relatar que "é melhor que eles permaneçam no abrigo". 
FAMÍLIA 5

Abrigada L, 17 anos, sexo feminino

Tempo de abrigamento: 5 anos.

Violência perpetrada: Violência Sexual.

Seu pai morreu por ter contraído HIV e a mãe mora no Estado do Mato Grosso e é profissional do sexo. Os pais eram negligentes com os filhos e não possuia vínculo afetivo com estes. A abrigada sofreu abuso do padrasto que só foi preso depois de abusar de uma vizinha que o denunciou. Aos oito anos de idade foi morar com o avô que logo depois faleceu sendo acolhida pelo irmão do avô (tioavô) e sua esposa. Apresentava inúmeros conflitos na casa do tio-avô e em um desses conflitos fugiu de casa e denunciou os tios por agressão física e abuso sexual por parte do tio-avô. Em 1999 foi abrigada pelo mesmo motivo da denúncia, foi desabrigada 2 meses depois sendo novamente abrigada. Depois de algum tempo, Lúcia desmentiu o abuso sexual sofrido pelo tio-avô dizendo que só fez isso para se vingar pois este não deixava-a sair. Enquanto esteve no abrigo engravidou aos 13 anos e teve sua filha quando foi desabrigada, passando por várias famílias. Em janeiro de 2004 foi abrigada por busca e apreensão sem responsável legal e sua filha ficou com a avó paterna. Segundo a psicóloga do abrigo, esta apresenta promiscuidade interacional e dificuldades na escola. 
FAMÍLIA 6

Abrigados: $\mathrm{R}, 9$ anos, sexo masculino.

$\mathrm{R}, 8$ anos, sexo masculino.

Tempo de abrigamento: 3 meses.

Violência perpetrada: Violência Física.

Mãe era profissional do sexo e abandonou os filhos em 2002 mudando para outro município.

Atualmente a composição familiar:

Madrasta, 25 anos.

Pai, 34 anos.

E, 4 anos, sexo feminino.

$\mathrm{R}, 5$ anos, sexo feminino.

$\mathrm{M}, 2$ anos, sexo masculino.

$\mathrm{V}, 3$ meses, sexo masculino.

Todos os filhos estão abrigados

No ano de 1998 houve uma denúncia por conflito familiar, negligência e violência física, mas as crianças não foram abrigadas. A mãe foi menina de rua criada na FEBEN e lá engravidou aos 12 anos abandonando seu filho, depois foi morar em uma casa de prostituição com a irmã.

Houve várias denúncias de negligência, violência física e abuso sexual. Crianças diziam que seu pai batia e colocava-os para olhar carros, além de presenciarem relações sexuais do pai com a namorada.

O pai atualmente está com morando com uma outra mulher que também foi profissional do sexo. Em junho do ano passado, com mandado de busca e apreensão, as crianças foram abrigadas. A mãe biológica reapareceu querendo a guarda dos filhos. 
$\mathcal{A N} \mathcal{N} X O$ 

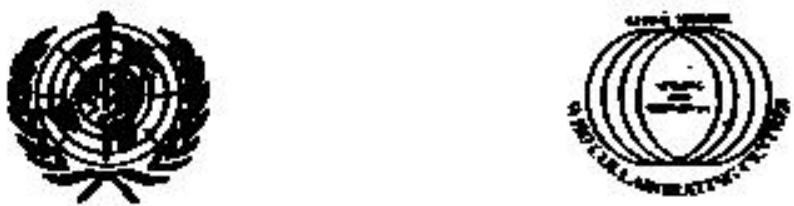

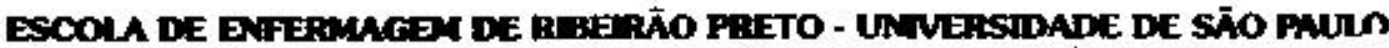

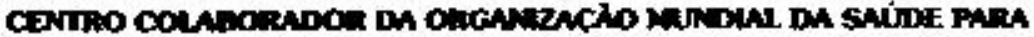

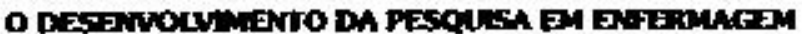

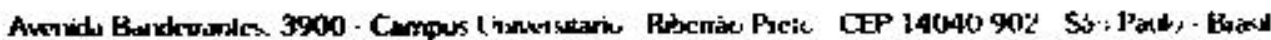

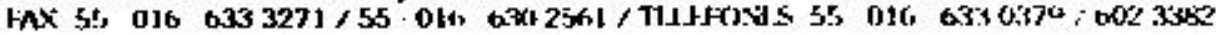

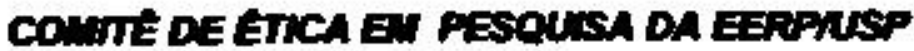

O.CEP-FERPNSP - 01042000

Ribeidio Preto, 20 de cutubro de 2000.

Prozada Senhora,

Comunicamos que o projelo memico de pesquisa - seus

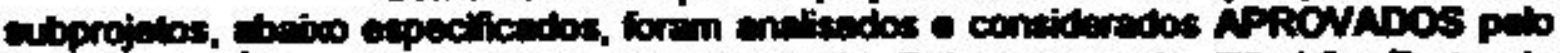

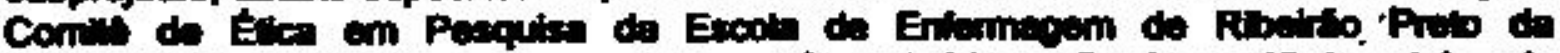

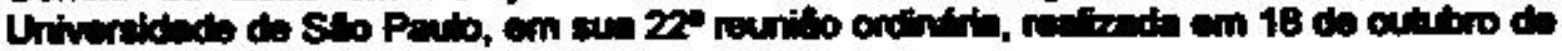
2000.

Protecelo CEP: $\quad$ in 01202000

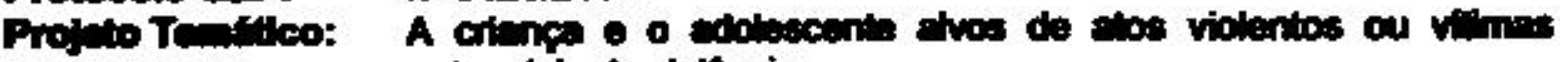
potenchis of violincia

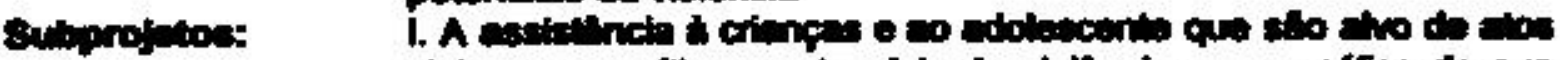

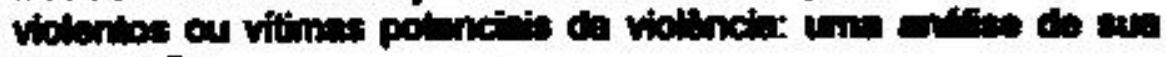
conetintofio;

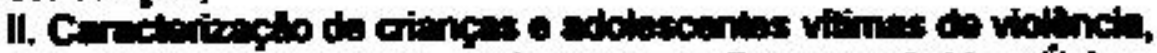

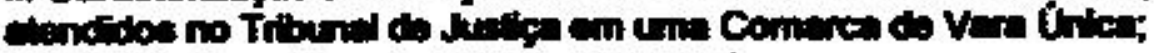

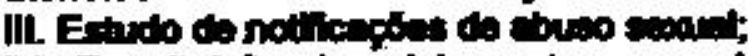

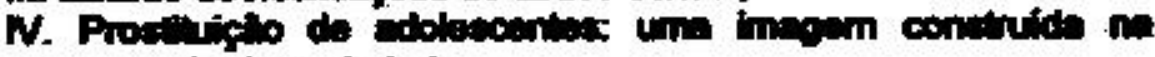
adveridede de sociodede.

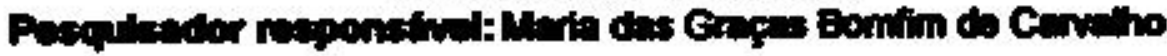

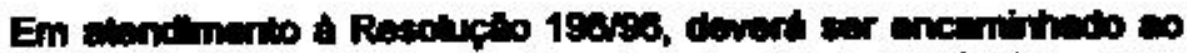

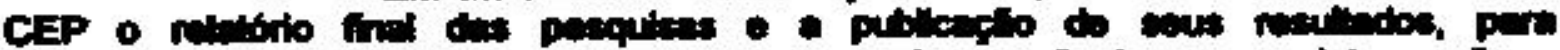

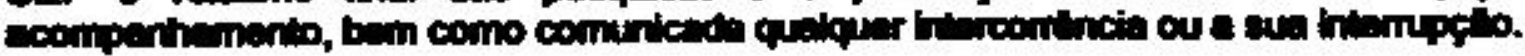

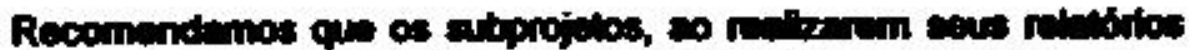

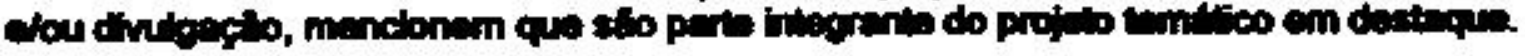

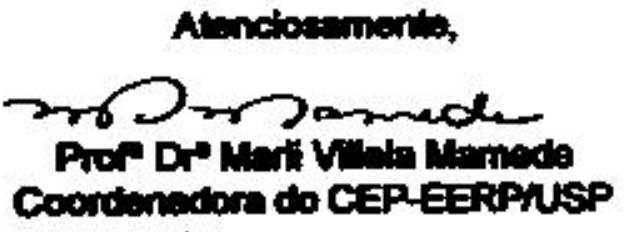

$\ln \mathrm{se}$

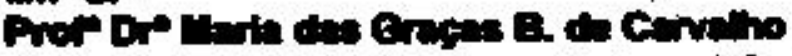

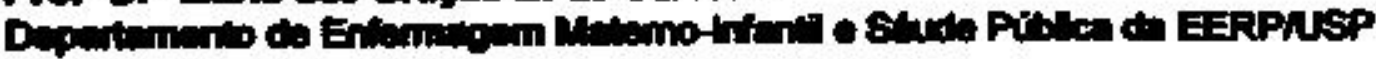

